\title{
Arbor
}

\section{Madrid, 1900. Sociabilidad, ocio y relaciones sociales}

\section{Francisco Villacorta Baños}

Arbor CLXIX, 666 (Junio 2001), 461-493 pp.

La sociabilidad, se suele repetir con frecuencia desde que tal concepto ha entrado con fuerza en la historia académica, saca su substancia de la historia social clásica, que pone el acento en las estructuras materiales condicionantes de la vida social, de la historia moderna de las relaciones sociales y de la más reciente historia cultural de lo social. Se contabiliza bajo estos parámetros una forma de atraer al campo histórico determinados fenómenos individuales y colectivos de carácter ritual, representativo y lúdico, no siempre bien comprendidos por la historiografía clásica, que involucra, como veremos a continuación, a los espacios sociales, las relaciones entre los grupos y las representaciones colectivas que rigen la identidad y los comportamientos de los individuos.

\section{Instantáneas}

Comencemos por algunas notas descriptivas que nos facilita la técnica moderna de la fotografía, recurso documental en absoluto accesorio puesto que tal fue, al menos hasta los años 20 del siglo XX, el papel más evidente reservado a este medio.

En una de ellas se reproduce la amplia panorámica de la Puerta del Sol mirando hacia la desembocadura del Madrid de los Austrias. A la izquierda la mole del Palacio de Gobernación, con su inconfundible torre y su reloj. Al fondo y a la derecha, el arranque de las calles Mayor, Arenal, Preciados y Carmen, con los edificios que les sirven de embocadura. Partiendo desde la derecha, en primer plano de la 
imagen, hacia esas calles se dirige el zigzagueante trazado de las vías del tranvía eléctrico. Dos de ellos, a distinta profundidad del cuadro, se dirigen, en efecto, hacia sus destinos. En escorzo sobre la derecha del primer plano, otros tres, del tipo jardinera, movidos todavía por tracción animal, se emplazan en las trayectorias proyecciones lejanas de las calles Mayor y Carmen. En la vecindad de todos ellos, coches de caballos de diverso tipo -simones, milords, landós, berlinas, ómnibusentrecruzan sus trayectorias caprichosamente. Hacia la izquierda, en una perspectiva intermedia, un carro transporta sus mercancías en la dirección del apenas entrevisto arranque de la calle Preciados. Sobre el empedrado, vehículos y figuras humanas esparcidas a voleo en solitario, en pareja, en grupo, atrapados en instantánea de tertulia o movimiento, en traje de calle, de trabajo o uniforme componen un caótico ballet que resume, sorprendido en un instante, el cuadro multiforme de la vida individual y colectiva del Madrid antiguo y moderno de comienzos de siglo ${ }^{1}$.

La Puerta del Sol hacia 1900

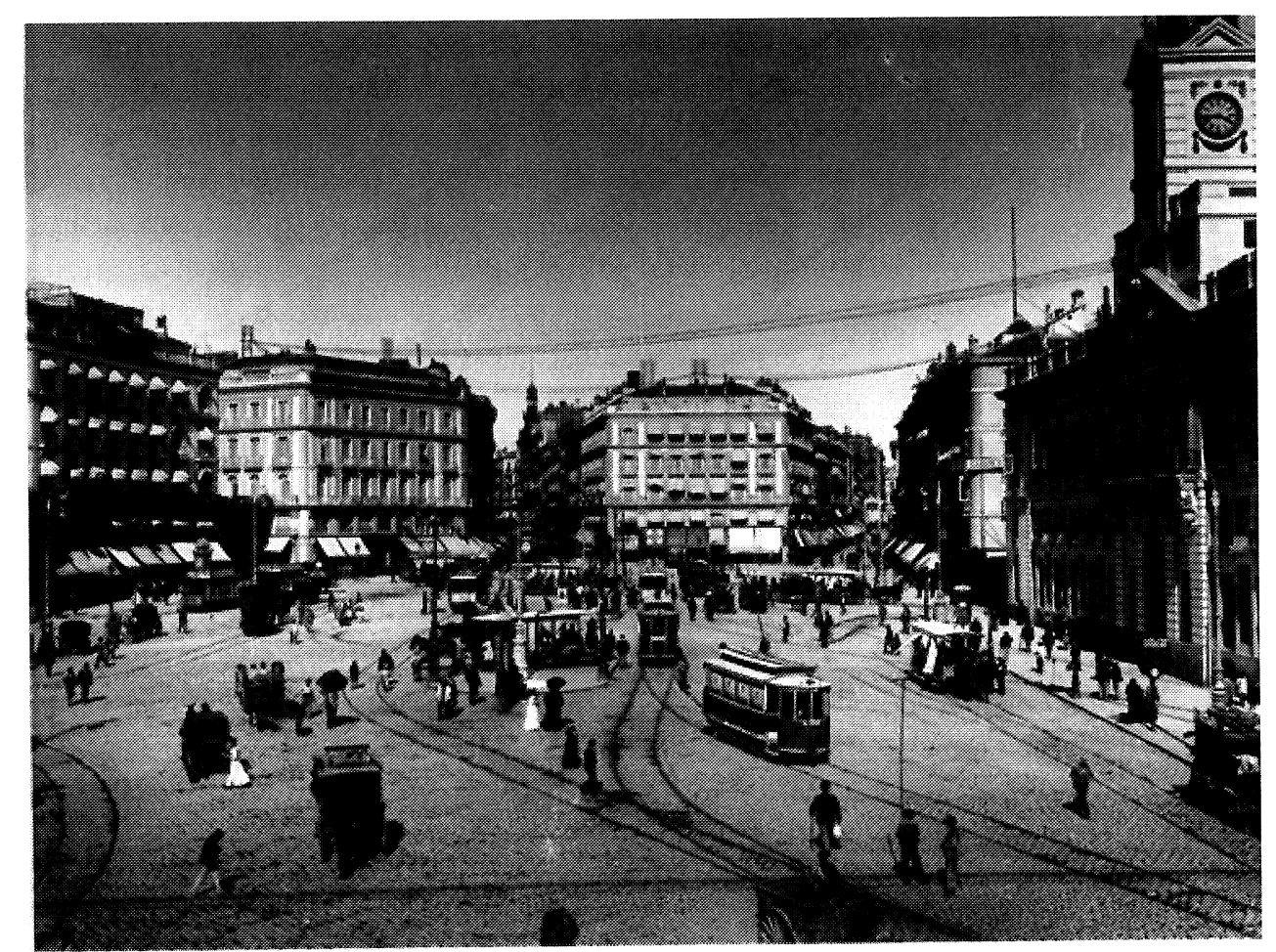


Madrid 1900. Sociabilidad, ocio y relaciones sociales

La Equitativa, Alcalá/Sevilla, a comienzos del siglo $\mathrm{XX}$

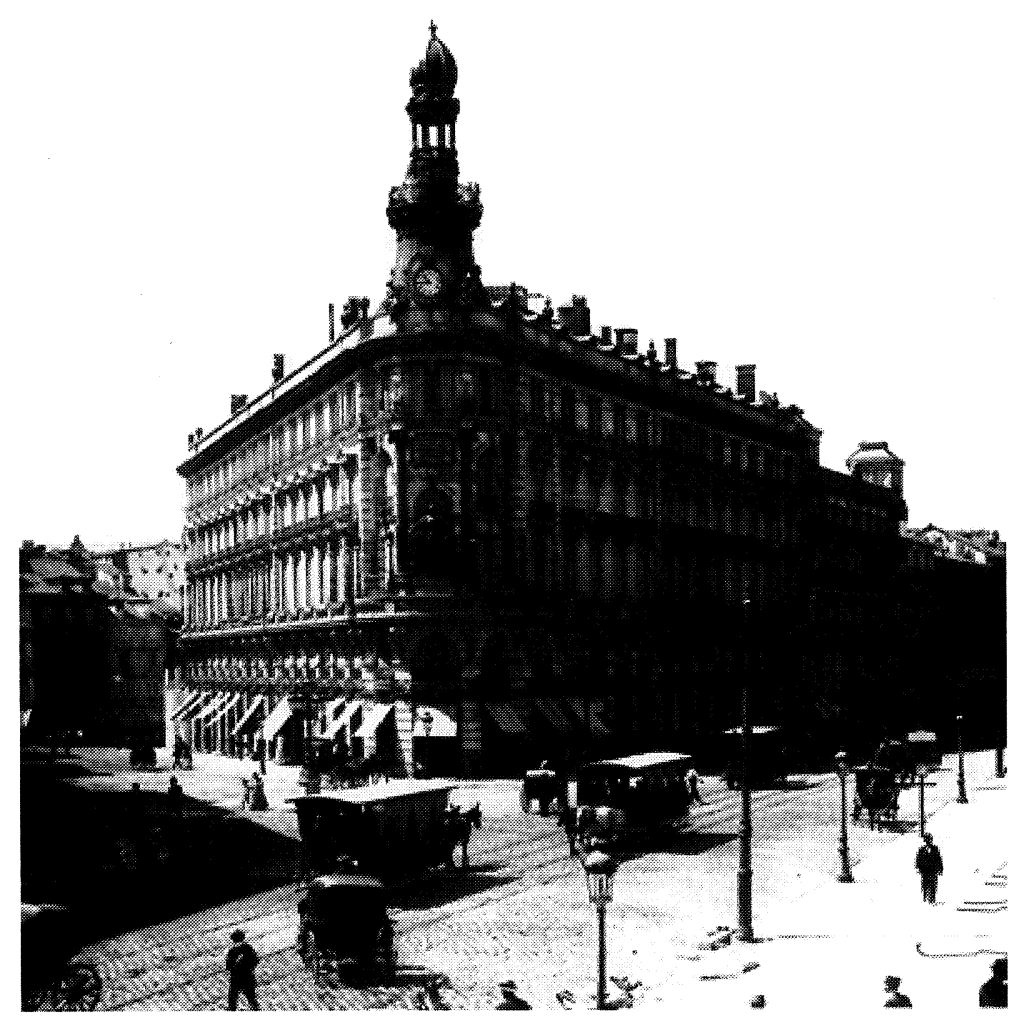

Demos la espalda a este cuadro y avancemos escasos centenares de metros por la calle Alcalá hasta situarnos ante un nuevo cuadro. El centro de la perspectiva se encuentra ahora dominado por el edificio imponente de La Equitativa, en la confluencia de las calles Alcalá y Sevilla. Como en el caso anterior, figuras humanas, jardineras, simones y milords entrecruzan sus trayectorias. Una larga hilera de éstos esperan ante la fachada derecha en sombra del edificio, a lo largo de la calle Alcalá. Si el fotógrafo hubiese logrado ampliar un poco la perspectiva hasta las inmediatas esquinas de las calles a derecha e izquierda hubiera logrado captar la imagen de dos de los más célebres cafés del Madrid finisecular: el Fornos y el Suizo ${ }^{2}$.

Continuemos el camino hasta llegar a la encrucijada presidida por la diosa Cibeles. Aquí la instantánea nos sitúa a la entrada del paseo de Recoletos. A la derecha se perfila el recién concluido Palacio de Linares, el único edificio claramente destacado en la amplia panorámica dominada hasta el horizonte por las tupidas copas de 
las hileras de árboles del paseo. Algún escaso vehículo - un tranvía eléctrico y un simón- destacados en un primer plano del ancho panorama y contadas figuras esparcidas aquí y allá completan el cuadro. Giremos ciento ochenta grados para afrontar un escenario no muy diferente al anterior: el Salón del Prado. Visto desde su vertiente sur, de espaldas a la fuente gemela de Neptuno, el amplio panorama de la instantánea se estratifica en tres segmentos que forman el cielo, las negras copas de la tupida arboleda, sobre las que solo se destaca nítidamente el edificio del Banco de España, y el macadam de primer plano. A veinte años de distancia y con una profundidad de campo aún más lejana, que incluye a la propia fuente de Neptuno, otra instantánea ratifica el protagonismo absoluto del ancho paseo arbolado en el que las figuras, y hasta los edificios, son como minúsculas figuras esparcidas por doquier.

El Paseo de Recoletos hacia 1905

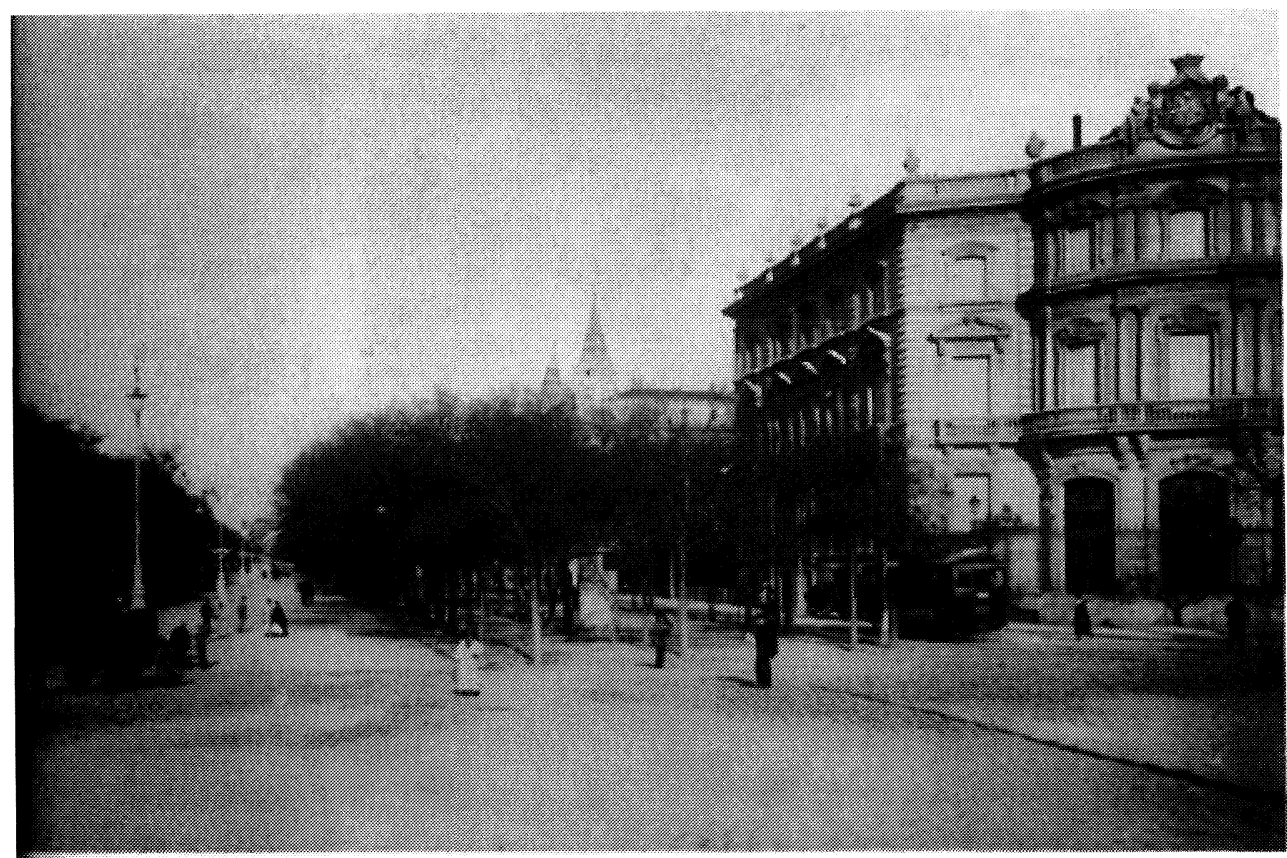


Madrid 1900. Sociabilidad, ocio y relaciones sociales

El Paseo del Prado en 1891

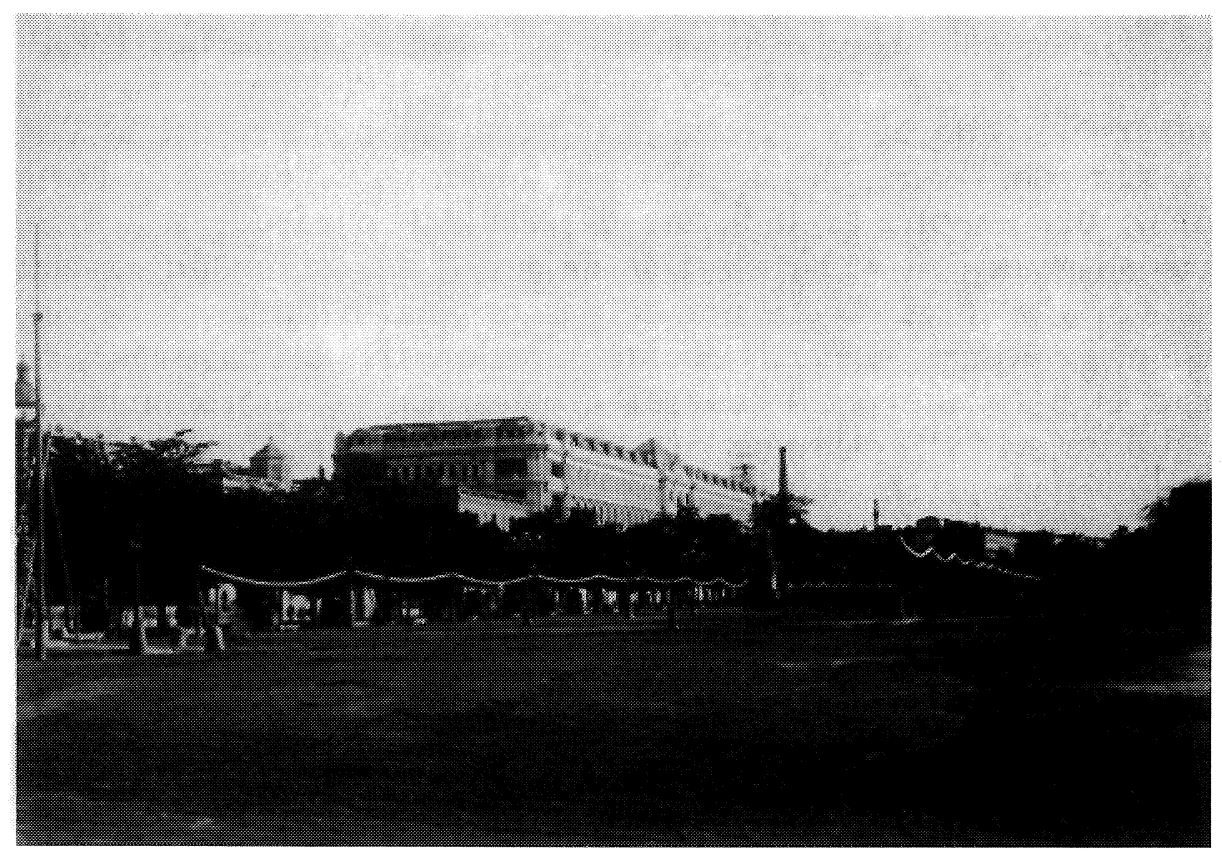

El Salón del Prado, a comienzos del siglo XX

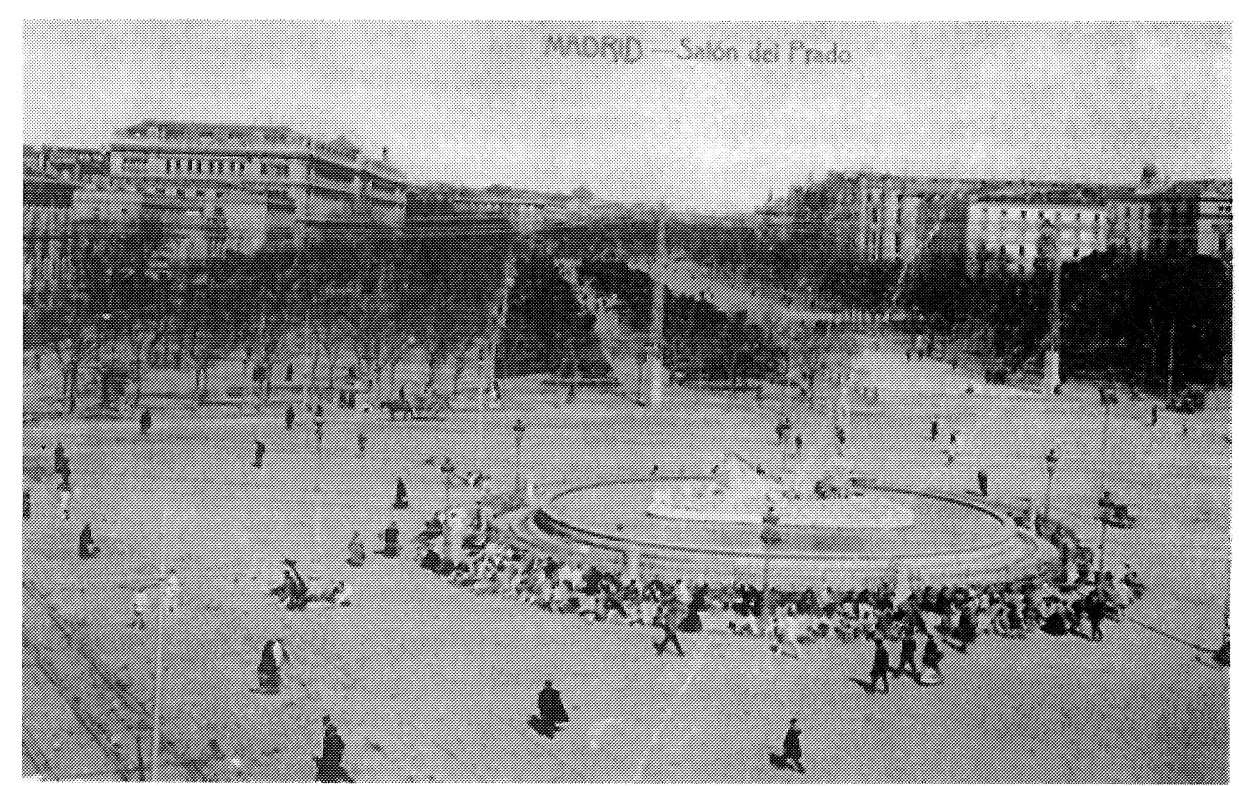


Retornemos a la calle Alcalá, dejemos atrás a la derecha, en el espacio del actual Palacio de Comunicaciones, el frondoso remanso de los Jardines del Buen Retiro tan celebrados por los noctámbulos del estío madrileño del último tercio del siglo, y sigamos hasta encontrar, más allá de la Puerta, el ingreso que nos conduce al Paseo de Coches del Retiro. Desde 1874, por iniciativa del duque de Fernán Núñez, una amplia avenida fue desarbolada para dar a la buena sociedad madrileña la satisfacción de oficiar sus ceremonias sociales desde lo alto de sus carruajes de paseo. Una instantánea de hacia 1895 nos muestra, en efecto, la amplia perspectiva del paseo escoltada hasta el horizonte por frondosos árboles. En el centro mismo del cuadro un solitario carruaje, de uniformado cochero, parece desafiar las convenciones rituales que regían los hábitos gregarios tanto en la exhibición pública como en el repliegue privado de los grupos sociales ${ }^{6}$.

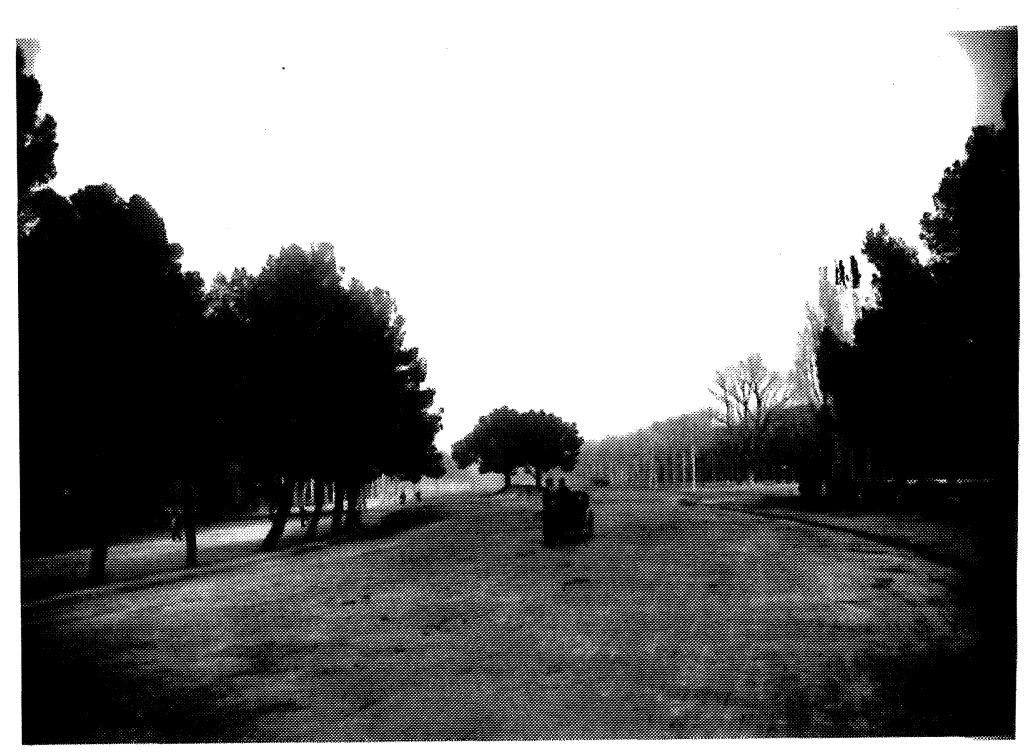

Reemprendamos la marcha por el antiguo camino de Alcalá hasta llegar a los arrabales. Allí, antes de llegar al puente de las Ventas del Espíritu Santo, el fotógrafo ha encontrado un motivo adecuado. La instantánea panorámica nos muestra a la derecha, en el primer y medio plano de un horizonte vertebrado por el camino alcalaíno y 
Madrid 1900. Sociabilidad, ocio y relaciones sociales

sus edificios de escolta, un pequeño edificio de dos pisos, el superior ocupado por un amplio salón en forma de galería acristalada. En su alero, el rótulo La Gloriosa, nombre de uno de los merenderos ubicados en la calle Almería descendente hacia el valle del arroyo Abroñigal. A la derecha, un pequeño pórtico da entrada al establecimiento. Al lado de aquél siguiendo la calle, apenas entrevisto en la instantánea, un segundo local del mismo tipo: Los Andaluces. Los figurantes, de evidente aspecto condición popular, esperan expectantes el milagro de la resolución de la cámara ${ }^{7}$.

Merendero La Gloriosa, en Ventas, hacia comienzos del siglo XX

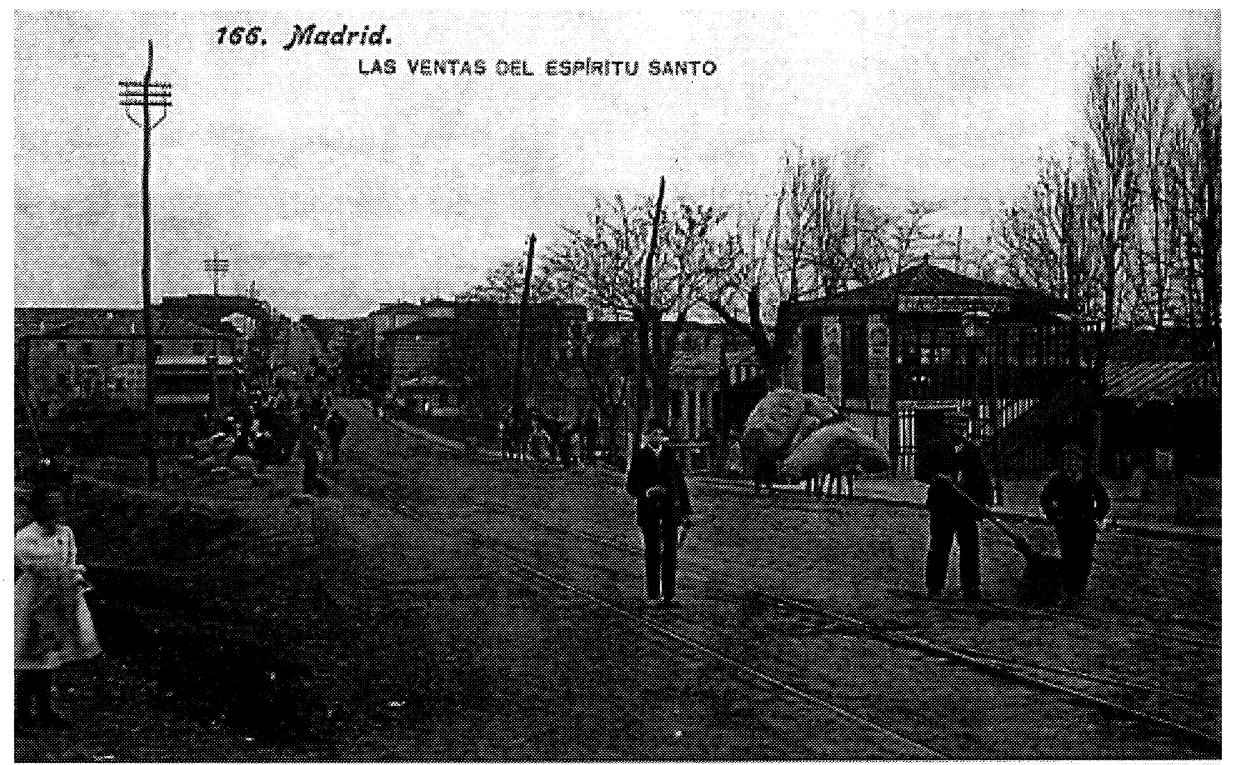

Trasladémonos desde estos arrabales a los que se emplazan en el eje del río Manzanares, en dirección al Pardo. Ahora la instantánea nos muestra, precedido de un pórtico emparrado y rodeado de frondosos árboles que escoltan todo el recinto, la perspectiva de un edificio de dos plantas con la fachada cubierta de reclamos publicitarios. En uno de sus paños, el rótulo: Viveros de la Villa, nombre de uno de los más celebrados merenderos durante la primera mitad del siglo XX. $\mathrm{Al}$ fondo, sobre la derecha, la elegante verja de entrada al patio, que enmarca el paso de un carro por el exterior, sobre un fondo, de nuevo, de arboleda ${ }^{8}$. Si, dando la espalda a la verja, avanzásemos unos centenares de metros por la frondosa vereda encontraríamos, en la misma vertiente, un edificio no muy diverso del anterior. La instantánea nos 


\section{Francisco Villacorta Baños}

lo muestra en perspectiva a la izquierda, empequeñecido por la imponente silueta de la arboleda que se pierde, hacia el fondo, hasta el horizonte. En el frontispicio, el nombre indicativo de la misma ocupación y popularidad que el descrito más arriba: Campo de Recreo. Hacia el centro del cuadro, en primer plano, un solitario simón avanza hacia el espectador.

Merendero Viveros de la Villa, en el camino del Pardo, a comienzos del siglo $\mathrm{XX}$

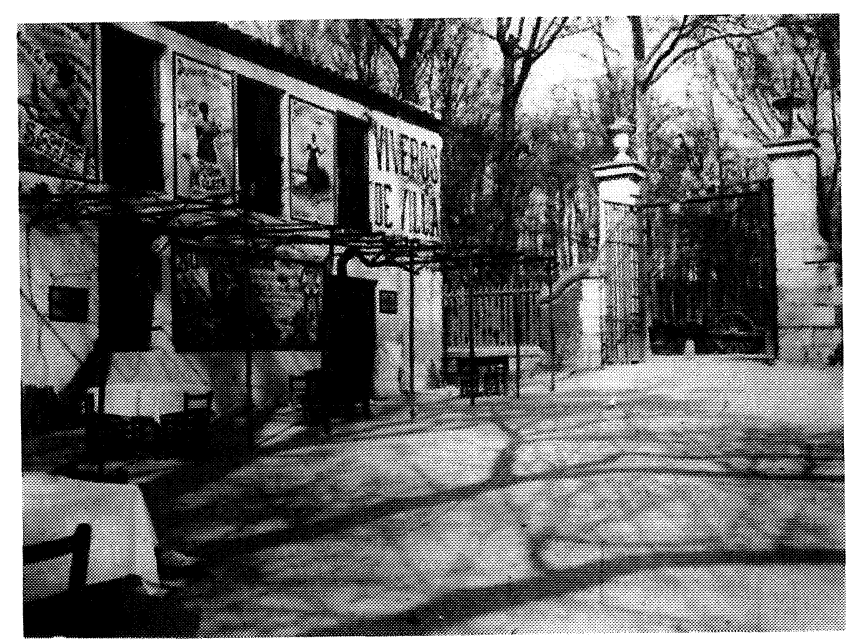

Merendero Campo de Recreo, en el camino del Pardo, a comienzos del siglo $\mathrm{XX}$

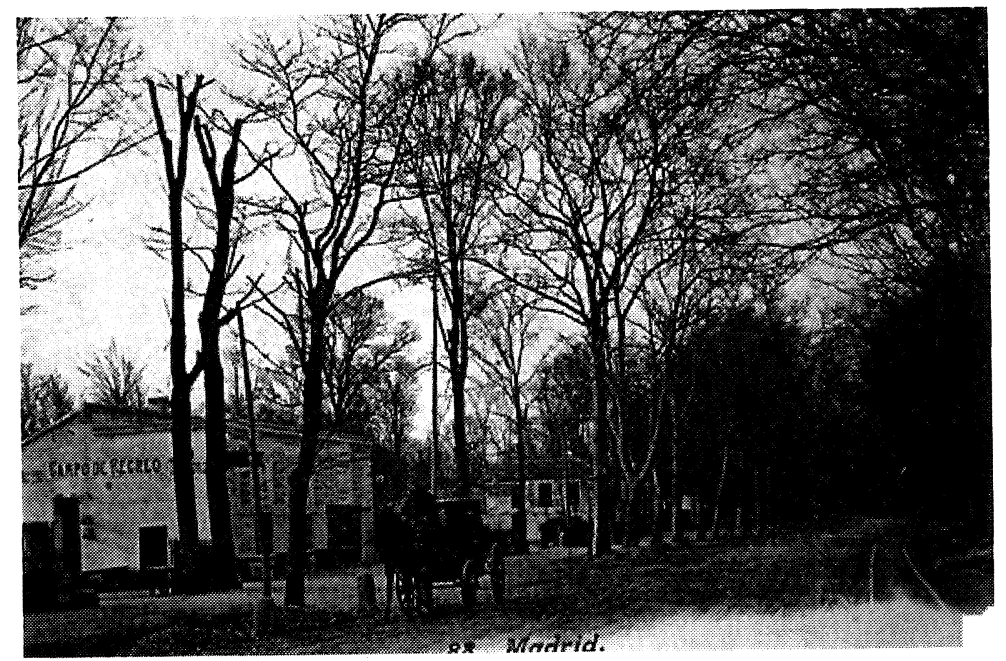


Madrid 1900. Sociabilidad, ocio y relaciones sociales

\section{Paisajes con figuras o «Biografía del 1900»}

Imaginemos ahora por un momento que las estáticas figuras, sorprendidas en un instante de sus ocupaciones cotidianas, de los cuadros descritos se ponen en movimiento y comienzan a agruparse conforme a los diversos núcleos de polaridad que constituyen su clase, su profesión, sus inquietudes culturales, sus aficiones, sus apetitos festivos, sus tendencias bohemias. Puede darse el caso, además, que el cuadro se encuentre en ese momento coloreado por los diversos acontecimientos religiosos, lúdicos o patrióticos que sacuden rítmicamente el pulso vital de la ciudad. O que bajo el protector resplandor de la iluminación callejera eléctrica inaugurada en enero de 1900 en algunas calles céntricas comience a difuminarse la ancestral alternancia entre sueño y vigilia de los ritmos naturales del tiempo, de forma que - parafraseando las palabras Antonio Flores sobre la imaginaria madrugada de 1899- desde que esa invención ha permitido «que la noche se eche el alma a la espalda, trocando sus negras tocas de viuda modesta y recogida por el esplendente ropaje de doncella alegre y enamorada, no hay medio de sorprender al alba en paños menores dentro de las grandes capitales» ${ }^{10}$.

Cuando todas estas circunstancias se producen los escenarios se repliegan ante el protagonismo de las figuras, impulsadas por algunas necesidades elementales de relación a través de la que se afirman las identidades sociales, se intercambian intereses, afectos y aficiones y se satisface la compulsión de reconocimiento público. Todos esos recursos se ponen en juego, en definitiva, en la dimensión sociable de lo social que es el primero de los pilares sobre el que queremos construir estas páginas. Ante ellos, el documento positivo fijado por la cámara, como aquellos que acabamos de describir, deja paso a las modulaciones cualitativas de la vida social. El segundo pilar es el de Madrid en torno a la fecha gozne de 1900. Sobre ambos datos, escenario y vida de sociabilidad, que hemos venido poniendo sobre la mesa, es posible construir la biografía social de un año, con la pretensión, como la que tenía el autor del libro bajo el que se cobija el rótulo de este epígrafe y que nos servirá de guía en todo momento, de que por el hueso de los trescientos sesenta y cinco días sea posible reconstruir el esqueleto entero de un período histórico ${ }^{11}$; de que por las rendijas de las aparentemente frívolas e intranscendentes reuniones festivas, celebraciones y efemérides lúdicas se entrevea el espectro complejo y problemático de las relaciones sociales. Tenemos por delante, pues, una «lectura de los signos», que cada uno de 
esos escenarios contiene, a través de la que, según dice Raphael Samuel, «el historiador ha sido capaz de tomar en serio la parte lúdica de la cultura humana y la vida social» ${ }^{12}$.

Madrid - se podría decir de forma general y por descontado en el campo que nos ocupa - es en el cambio de siglo un organismo híbrido, en plena evolución entre lo viejo y lo nuevo. Sería aventurado decir que en esta coyuntura concreta la vida social del todo Madrid ha cambiado de forma significativa respecto al floreciente cortesanismo isabelino y a la pujante ostentación burguesa de la primera Restauración y la Regencia. Los viejos rituales de sociabilidad en torno a la Corte y al gotha aristocrático se mantienen en apariencia inalterables. Tomemos como guía las descripciones en primera persona de la mencionada biografía madrileña del 1900. El joven estudiante de derecho, meritorio del ministerio de Estado y aprendiz de escritor y sus alegres amigas aristócratas, las Laguna especialmente, son un ejemplo paradigmático de la vida social de ese medio. Tienen abiertas, en primer lugar, por su propia posición o por sus relaciones, las puertas del núcleo central de irradiación simbólica de la representación social: el Palacio Real. Allí asisten, como protagonistas o espectadores, «enmarcados en la gloria del resplandor real» (p. 25) a los viejos rituales cortesanos vinculados a las onomásticas y celebraciones religiosas o laicas, que «han conservado toda su etiqueta antigua» (p. 33): la capilla pública del 6 de enero y del domingo de Ramos, el santo del Rey el 23 del mismo mes de enero, el lavatorio de los pies el día de Jueves Santo, el baile chico («cogollo aristocrático», frente a la mezcla de aristocracia y burguesía del «baile grande», p. 197) de 9 de mayo, el "garden party» en el Campo del Moro el 17 de junio.

$\mathrm{Al}$ amparo de este centro legitimador se cobija una todavía pujante vida de sociabilidad de los medios aristocráticos y altoburgueses. A lo largo del año, con el pretexto de idénticas efemérides de la vida individual, religiosa y colectiva, se teje una tupida red de relaciones personales y de hábitos culturales sobremanera definitorios de la identidad de una clase social. Sigamos algunos de ellos cronológicamente según el agudo relato del libro que nos ocupa. El paseo es uno de los rituales universales de la sociabilidad, en que el autor sorprende a sus personajes tanto en verano como en invierno (p. 20), a pie como en carruaje, por el Retiro, la Casa de Campo (p. 30), el Prado, Recoletos o por la Castellana, que ha ido pasando al primer plano de la moda conforme se urbanizaba y conforme sus predecesores, el Prado y Recoletos, se han visto relegados en su función selectiva y diferenciadora por la propia atracción de su éxito mundano. 


\section{Madrid 1900. Sociabilidad, ocio y relaciones sociales}

Instantáneas. La primera de ellas recoge la apiñada procesión de personajes de diversa condición social por el paseo de Recoletos todavía en plena temporada invernal. Caminando bajo el amplio arco de los árboles del paseo, en circuito de ida y vuelta, con predominio de gabanes y sombreros hongo ellos, gruesos talares y sombreros ellas, o bien detenidos en el lateral izquierdo en la contemplación del tránsito humano, consustancial al fenómeno mismo del paseo, dejan al otro lado varias abigarradas hileras de sillas, ahora vacantes, a la espera de mejores condiciones climáticas ${ }^{13}$.

$\mathrm{Y}$ esto es lo que recoge la segunda de las instantáneas. Bajo la tupida fronda de la arboleda grupos diversos de personas en traje veraniego hacen tertulia o simplemente contemplan con placidez el paso del tiempo sentados en las sillas del paseo, mientras el cobrador del alquiler, a la izquierda, se apresta a cobrar el óbolo ${ }^{14}$.

El Paseo de Recoletos, a comienzos del siglo XX

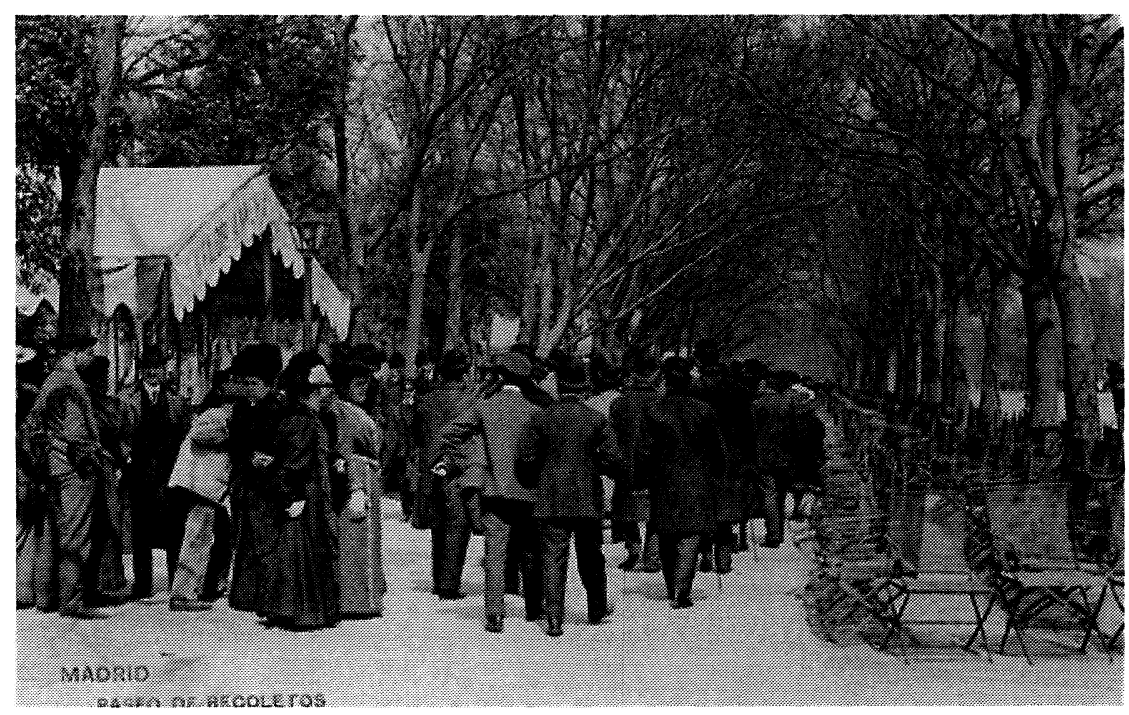

En febrero se emprende la tarea, tan ardua «como la de formar un gobierno», de emparejar «la lista grande» de los jóvenes herederos que bailarán en el palacio de Villahermosa la dieciochesca pavana organizada por la ambiciosa marquesa de Squilache (pp. 98-99 y 102110), uno de esos personajes omnipresentes, en su búsqueda compulsiva de un lugar entre los grandes del gotha aristocrático, de la vida social madrileña en las décadas de cambio de siglo. Casi de inmediato comienzan las celebraciones de carnaval: el desfile de carrozas y máscaras 
organizado por el Ayuntamiento de Madrid con el Paseo de Coches del Retiro, su punto de partida, como selecto centro de exhibición, con tribunas reservadas para el Jurado, la familia real, la Gran Peña, el Casino, el Nuevo Club, amén de otras reservadas a quienes tengan capacidad para pagar las veinticinco pesetas del palco; la batalla de confetis y serpentinas del lunes de Carnaval en Recoletos; los bailes de máscaras en el Circo de Colón, en el Teatro Nuevo, en la Embajada de Italia, en el Teatro Real organizado por el Círculo de Bellas Artes; el goyesco entierro de la sardina el miércoles siguiente en la Pradera del Corregidor.

Tertulias veraniegas en el Paseo de Recoletos

a comienzos del siglo $\mathrm{XX}$

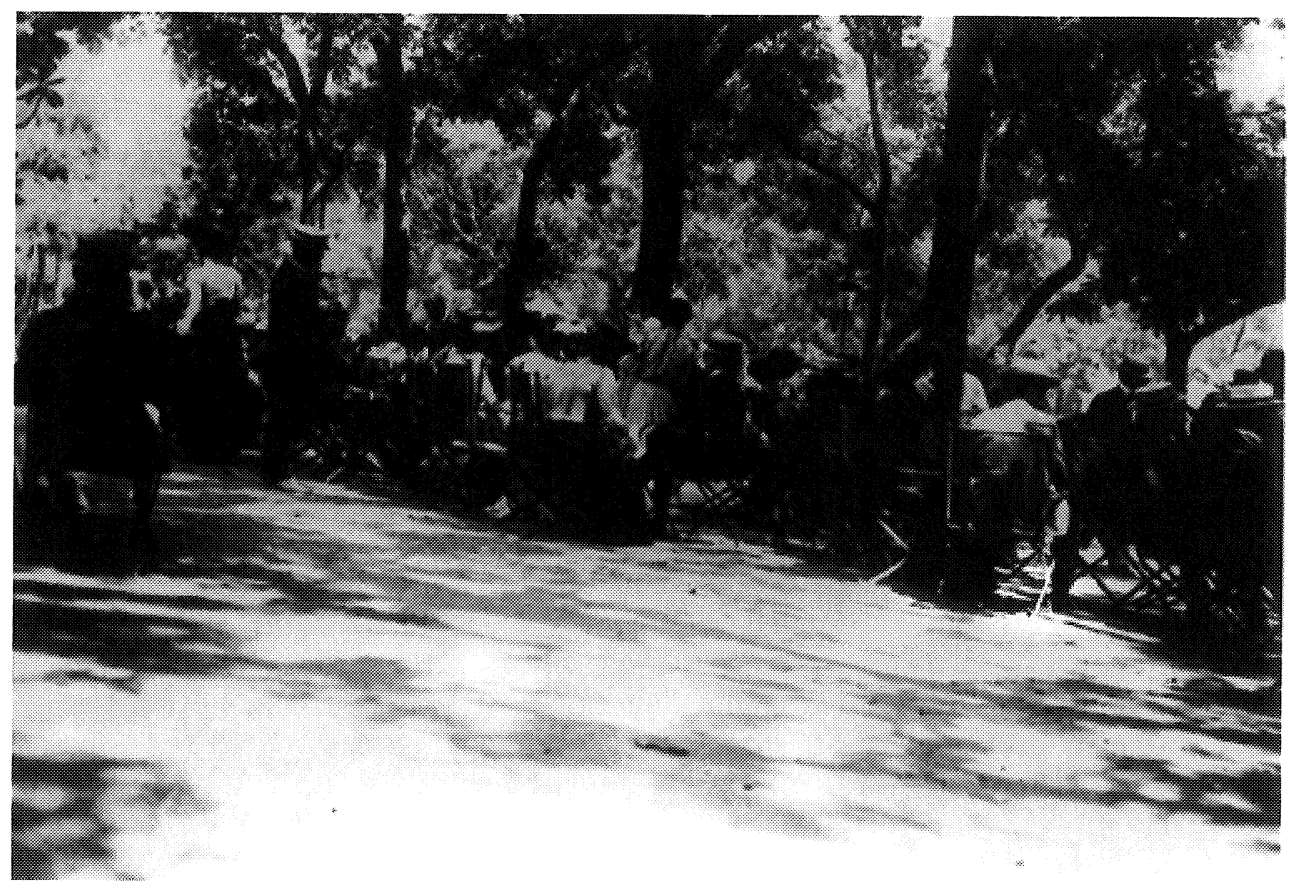

Excurso. El Casino, la Gran Peña, el Nuevo Club, los tres centros selectos de Madrid cuya importancia como signo de identidad social resulta incuestionable por su comparecencia institucional en la mayor parte de actos de representación pública, lo que hace que pueda no conocerse la identidad individual de las personas acogidos a su sombra, pero que no exista duda alguna acerca de la social: «chicos de la Peña y del Nuevo Club» de los Jardines del Buen Retiro (p. 223), los «jóvenes del "Nuevo Club"» que imponen la moda de quedarse en mangas 
Madrid 1900. Sociabilidad, ocio y relaciones sociales

de camisa en los toros (p. 170). El Casino, el más antiguo, data de 1837 y acoge desde entonces a buena parte de la sociedad adinerada de Madrid a la búsqueda de relaciones interpares, una proyección identitaria pública y un cobijo seguro para los atrapados por la fascinación de los juegos de azar. La Gran Peña, a continuación, tertulia de militares nacida en el café Suizo en 1869, instalada después en sede independiente en la calle de Alcalá, justo al lado del Suizo antes de abordar, ya en la segunda década del siglo XX, el proyecto de casa propia. El Nuevo Club, finalmente, nombre definitivo del Veloz Club, selecta reunión aristocrática de orientación alfonsina nacida en 1873 en torno a deportiva afición por el velocípedo ${ }^{15}$.

La fiesta pagana da paso sin solución de continuidad a la religiosidad mundana de la cuaresma y semana santa. Se habla de los predicadores y ejercicios espirituales más «chic» (p. 124); se aprovechan los oficios religiosos y la visita a las estaciones para exhibir por la calle de Alcalá los empavonados trajes de gala - mantilla, peineta y vestidos de seda negra ellas; uniformes de gala militar, levitas y sombreros de copa, talares de las órdenes militares ellos- «las mismas personas del «foyer» del Real», con «otro indumento» y con una alegría en apariencia impropia de la efemérides religiosa (pp. 163-167).

Por entonces está a punto de romper la primavera y con ella llegan los días más felices de los paseos cotidianos de coches alrededor del Angel Caído en el Retiro, aquellos en que los carruajes, rebosantes de mujeres jóvenes, se abren al sol y se engalanan de flores. Son la celebración suprema del gusto morboso de la aristocracia por su propia contemplación. Comienza la procesión de carruajes hacia las cuatro de la tarde formando una especie de larga línea de tribunas «desde las cuales se puede, con toda comodidad, mirar y ser mirado». A la caída de la tarde, de repente, todos ellos se dirigen hacia la Castellana, donde se repiten las escenas del Retiro y todavía al anochecer la procesión emprende la marcha, calle Alcalá adelante, hacia el corto y estrecho trayecto de la carrera de San Jerónimo entre las cuatro calles y Sol, donde las aceras se pueblan de «gomosos, que, a su vez, contemplan ávidamente a las bellas» (pp. 193-197), en tanto que los protagonistas aprovechan para pasar un momento por Lhardy para degustar una copa de jerez antes de retirarse al calor del hogar.

Todo lo mencionado mientras el paso del tiempo va punteando los días con hábitos y relaciones que densifican la urdimbre de ese universo cultural: la dedicación o asistencia a los tradicionales deportes aristocráticos -el tiro de pichón, las carreras de caballos, cuya procesión de carruajes a la salida del hipódromo de la Castellana se convierte 
en sí misma en un espectáculo público amparado por el Ayuntamiento (pp. 200-202) - o a los nuevos deportes a la moda: el polo, que es «el más chic de los deportes» (p. 139), lo que quiere decir fundamentalmente el más caro, ya que exige la capacidad para mantener una cuadra de jacas. («Hasta ahora solo juegan Jimmy Huéscar (Alba), el duque de Arión, Justo San Miguel, Valentín Menéndez (hijo de los condes de Vilches), algún diplomático de la embajada británica y pocos más», p. 140), la bicicleta, el novísimo automóvil o el «tennis», recién importado de Inglaterra (p. 214); la tertulia cotidiana del marqués de Miraflores en el palacio Martorell de la carrera de San Jerónimo, los salones de la marquesa de Mérito y de la duquesa de Bailén, las recepciones de los príncipes de Wrede, recién establecidos con gran estrépito mundano en Madrid, el santo de la marquesa de Ivanrey, la interminable ronda de felicitaciones el día de San José, el Santo de la Pardo Bazán el 5 de abril, otro de esos personajes ávidos de vida y representación social en el Madrid de cambio de siglo (pp. 158-161) ${ }^{16}$.

Instantánea. Una composición de estudio nos muestra a la Pardo Bazán en el centro de una de estas reuniones domiciliarias: las damas de elegante atuendo sentadas en semicírculo en torno a una mesa y escoltadas por un coro de caballeros de pie, atentos la mayoría al movimiento de la cámara, bajo un fondo, todos ellos, de un convencional rincón familiar, con foto de familia y reloj de pared ${ }^{17}$.

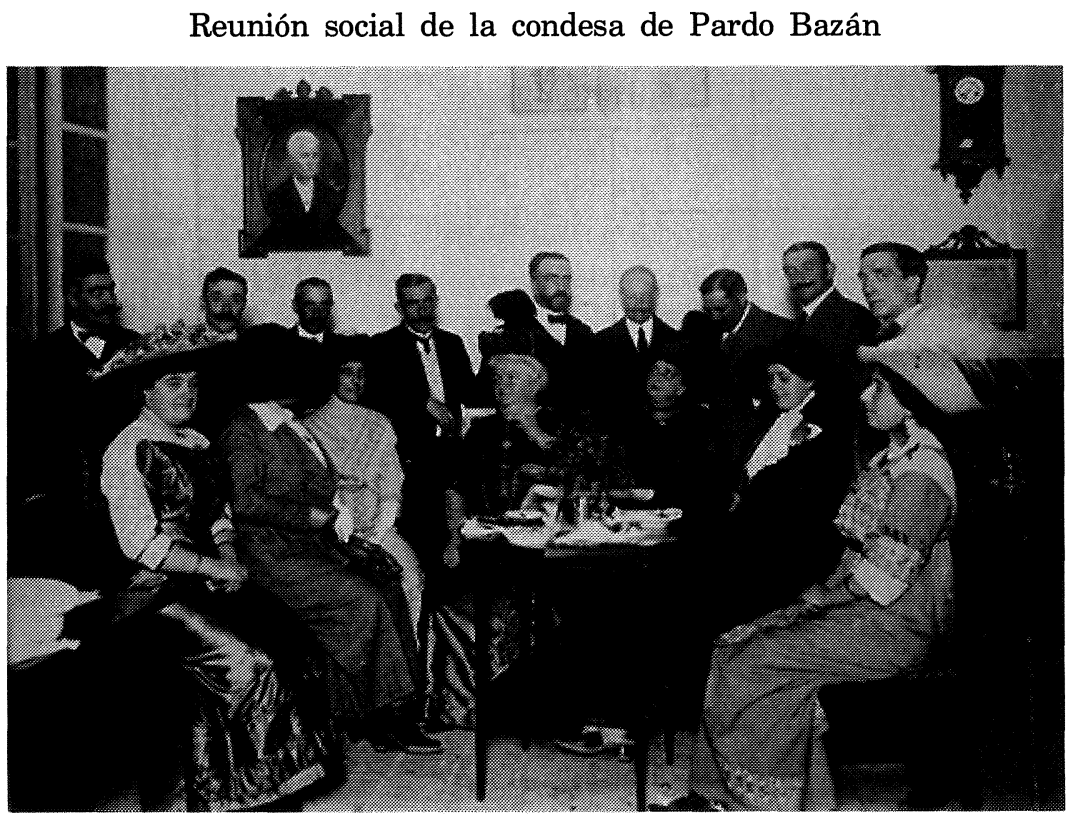


Madrid 1900. Sociabilidad, ocio y relaciones sociales

Con la bonanza metereológica cunde al mismo tiempo un compulsivo afán de fiestas y celebraciones: San Isidro, baile en casa de Bailén, bailes en Palacio, fiestas de San Fernando en Aranjuez, nuevos bailes en casa de la Squilache, corridas de toros, baile en la Embajada de Inglaterra, verbena en casa de la Bermúdez de Castro (la «falsa reina», por su parecido con María Cristina). Así hasta que la corte se desplaza a San Sebastián para el veraneo. Los rituales permanecen aunque los escenarios sean ahora la Concha, el boulevard, las sidrerías o el Casino. Pero este es solo una de las posibilidades, porque el veraneo se ha estratificado conforme se ha hecho más general: Biarritz y el extranjero para los círculos más selectos; San Sebastián para los patriotas y cortesanos meritorios, que la convierten, en verano, en una ciudad «rematadamente cursi» (p. 231); La Granja después y por último los pueblos del Guadarrama, «con el mesocrático Escorial a la cabeza» (p. 216-218).

Para los que permanecen en Madrid, por un tiempo o durante todo el verano, es el momento dorado de los Jardines del Buen Retiro en el esquinazo del Prado y Alcalá. Su éxito reside, según el autor, no sólo en la frescura nocturna de su floresta, sino en «el prestigio que guarda en España la aristocracia», porque los Jardines permiten que «el olimpo se ponga en contacto con los mortales». Allí coinciden al fresco de la noche las diosas de la elegancia, los políticos más renombrados, «los tenores y primeras tiples de la zarzuela social», como toreros de paso, cupletistas y cronistas de sociedad, con las inquilinas de los «terceros sin ascensor». Allí se pasea interminablemente alrededor de la pista, se hace tertulia en las sillas que la rodean, se asiste al teatro allí levantado por Ducazcal y a otros espectáculos al aire libre, se baila y, en general, se da curso al comentario de actualidad, al ingenio elegante y a la maledicencia (pp. 219-223) ${ }^{18}$.

Excurso. Los jardines del Buen Retiro son únicamente uno de los más celebrados escenarios de la vida social al aire libre entre 1876 y 1905. Junto a ellos, de entre todos los acondicionados con diversa fortuna a lo largo del XIX, perviven en el final de siglo los Jardines de aclimatación de la calle de Ferraz, el Parque de Rusia o Madrid Moderno, en torno a la actual avenida de los Toreros, junto a la plaza de las Ventas; el de Salamanca en el barrio homónimo. Todos ellos, para diferenciarlos de los paseos y escenarios públicos ya mencionados, como el Prado-Recoletos-la Castellana, el Parque del Retiro o la Casa de Campo, combinan el disfrute de la naturaleza con espacios de ocio de carácter gratuito o de pago, como juegos de entretenimiento, conciertos, tiro al blanco, columpios, exhibición de animales domésticos, 
fondas, pistas de baile y de patinaje, espectáculos circenses, canales navegables, cafés, etc.. El propio año de 1900 se abren algunas de las atracciones de un ambicioso proyecto - que finalmente terminará fracasando- de unos Nuevos Campos Elíseos en la Quinta de la Fuente del Berro, en sustitución de los existentes desde 1861 a la entrada del actual barrio de Salamanca, desaparecidos veinte años atrás ${ }^{19}$.

Hasta prácticamente octubre-noviembre no se reanuda el curso de la vida social madrileña. Lo hace con la presentación de las novedades teatrales, la reapertura del año político y el retorno de las recepciones en casas particulares. La primera solemne del año es el 4 de noviembre, día de San Carlos, casa del barón de Castillo de Chirel, donde se repasan las recientes jornadas estivales y se hace recuento de lo último en chismes y en moda extranjera (pp. 248-251). La Squilache retoma a continuación sus viernes de tresillo. Se celebra el santo de la marquesa de la Laguna y hasta el de un personaje a la vez tan ajeno y tan necesario al escenario de la representación mundana, el cronista social Montecristo, el que, junto con los otros a la moda, Madrizzi y El Abate Faria, proyecta sobre el espacio público, a través de un codificado discurso que reparte calificativos de belleza y elegancia conforme a la tarifa mundana del momento, la jerarquía simbólica de las posiciones sociales (pp. 255-261). Que no son pocas ni fácil de discernir convenientemente. Hay - dice el autor al respecto- personas a cuyas casas se puede ir, pero a quienes no se debe recibir en casa; otras a quienes es posible frecuentar durante el veraneo, fuera de Madrid, pero no en la capital; algunas con quienes se puede tratar en el restaurante, pero no en el domicilio particular; otras con las que no es posible trato alguno y, finalmente, aquellas de las que se codician todas las combinaciones mundanas, aunque ellas habitualmente no lo permitan: los Alba, Medinaceli, Fernán-Núñez (pp-150-151). Y en fin, se prepara a conciencia el último de los actos religioso-mundanos del año: la misa del gallo. La más elegante de todas tiene como marco la iglesia de las Calatravas, que atrae lo más granado de la nobleza ataviada para la ocasión con sus galas más representativas. Pero también se ofician celebraciones particulares en la capilla de Palacio, en los palacios de Cervellón, Liria, Denia, Santo Mauro, en las casas aristocráticas de Squilache, Argüelles, Villalba, Somosancho, Linares, Pardo Bazán, Castillo de Chirel, Xifré y otros, seguidas de suntuosos ágapes escapados por los pelos de los rigores de la preceptiva vigilia del día 24 .

Pero este cuadro social no quedaría, sin embargo, completo si no captásemos, al mismo tiempo que sus peripecias, el discurso crepuscular en que se encuentra descrito, al que no son ajenos ciertamente los 
Madrid 1900. Sociabilidad, ocio y relaciones sociales

mecanismos selectivos con los que al cabo de más de cuarenta años transcurridos la memoria opera sobre los sucesos vividos: un discurso distanciado y sardónico de registros varios de una juventud plenamente interesada en las posibilidades de sociabilidad de su medio social, pero al mismo tiempo asumiéndolas como un repertorio de gastados rituales, hasta cierto punto ajenos, a los que convierten ocasionalmente en riptus, a veces ingenioso, a veces escéptico, a veces irónico, y en ejercicio de la distinción social transmutada en una nuevas fórmulas de diferenciación simbólica no convencionales, como la extravagancia. Señalemos tres ejemplos significativos. Cuando Blanca, la hija menor de los marqueses de la Laguna y otras amigas de ilustre cuna - nos cuenta el autor- pasean en los primeros días de enero por la Castellana lo hacen, a pesar del frío, por el andén de sombra para dar en la cabeza a las cursis del andén de sol, que poco a poco, ante esta extravagancia del poder y del prestigio social, comienzan a sentirse ridículas (p. 20). Otro ejemplo: aprovechando su hábito de mezclar los sucesos del día con la reseña de los actos sociales, el autor se vale de la preocupación coyuntural por una plaga de langosta aparecida de aquel verano del 900 para arremeter cáusticamente contra la que por las mismas fechas arrasa la cubertería real en el garden party del Campo del Moro (p.211). Pero sin duda nada ilustra mejor este clima crepuscular de una época dorada de la representación social que el cuadro con que el autor describe la última visita a Madrid de la princesa Rattazzi, una de las más célebres animadoras de la vida social y literaria de las capitales-corte europeas durante las últimas décadas del XIX, y el banquete de despedida de su grupo de adeptos madrileños. Allí, en un cálido ambiente de despedidas, el descontrol de las emociones hace caer literalmente la máscara del afeite y la representación para dejar al descubierto el rostro de la decadencia física y de la premonición de la cercana muerte, que efectivamente alcanzará a la princesa apenas año y medio más tarde (pp. 40-46)

El segundo universo de sociabilidad sugerido en nuestro libro-guía es el que tiene que ver con las aficiones literarias de su autor. En la anotación del 12 de febrero nos trasmite sus impresiones de la tertulia modernista del café de la Montaña (en la puerta del Sol, esquina a Alcalá, en los bajos del Hotel París, en parte del espacio antes ocupado por el café Imperial ${ }^{20}$ ) de la que son los más asiduos Aben-Humeya, Llanas Aguilaniego, Valle Inclán, Benavente, Camilo Bargiella, el grafista Ricardo Marín, el editor Bernardo Rodríguez, el actor bohemio Barinaga, Henry de Cornuty, un parisino omnipresente entre más arrastrada bohemia del Madrid finisecular, Bernardo G. de 


\section{Francisco Villacorta Baños}

Candamo y el segundo de los hermanos González Blanco, Pedro, entre otros (pp. 91-98).

Poco después, igualmente introducido por Aben-Humeya, lo hace de la tertulia del café de Madrid, un local lóbrego y tristón comparado con el anterior, aunque tal vez más «denso» de ideas, emplazado en la carrera de San Jerónimo, de la que son pontífices máximos Pío Baroja y José Martínez Ruiz. Son habituales allí los hermanos Fuxá, el inevitable Cornuty y un suizo políglota llamado Pablo Schmitd. De ambas tertulias resulta además asiduo Santiago Rusiñol, en sus estancias en Madrid (pp. 110-115) ${ }^{21}$.

En ambas semblanzas, así como en las corrientes anotaciones sobre las novedades literarias, especialmente las teatrales, se desvela la rudeza de la pugna, bien conocida por lo demás, entre continuidad y cambio dentro de ese mundo: el aprecio común por Rubén Darío y el rechazo de los viejos valores de la novelística realista y del neoromanticismo teatral. Echegaray es, entre los viejos, el principal motivo de escarnio, mientras que, en algunos casos, se reitera un aprecio distante por Galdós, Valera y la Pardo Bazán. Pero el cambio está en el candelero de todos los ambientes literarios, aunque sus protagonistas pasen comunmente todavía, como los antiguos románticos, por «melenudos, afeminados, lloricones y grotescos» (p. 93).

Excurso. Hay en estas pinceladas impresionistas de la vida literaria del Madrid finisecular algo que pertenece genéricamente a la sociología de la cultura moderna y algo que tiene que ver más particularmente con el proceso de renovación del mundo literario español de comienzos del XX. En efecto, este tipo de reuniones hunde sus raíces, especialmente a partir del romanticismo, en las necesidades de afirmación psicológica y social del artista que ha roto sus vínculos con lo que podríamos llamar modo de producción artística del Antiguo Régimen y que emprende el camino hacia el nuevo campo de ejercicio institucionalizado de la creación artística de tipo moderno. Estas reuniones cumplen, así, las funciones de afirmación colectiva en los nuevos cánones artísticos y de comparecencia común ante los nuevos públicos. El círculo, el cenáculo, la reunión de escuela, la bohemia son características sociológicas de la creación y difusión artísticas desde el romanticismo, aquellos fenómenos que se encuentran, a pesar en ocasiones de su apariencia anodina y frívola, en el centro mismo de la oposición entre academicismo artístico e innovación, que resume genéricamente la dinámica del arte moderno.

Sobre estos datos se superpone la coyuntura específica de transformación radical del campo artístico español de cambio de siglo, que 
Madrid 1900. Sociabilidad, ocio y relaciones sociales

refuerza sus rasgos de sociabilidad informal y heterodoxa. Se podría decir que si los predecesores son en su gran mayoría hombres de salón - los Campoamor, Núñez de Arce, Pelayo, Valera, que no daban abasto a las peticiones que se les dirigía para recitar sus versos inspirados por la viril prosa española, señalaba literalmente la princesa austríaca conocida por el pseudónimo de comte Paul Vasili ${ }^{22}$ - los modernistas y hombres del 98 son hombres de café, de calle, de tribuna pública como el Ateneo, ya en esta época más cultural que política, más intelectual que mundana. «El café era gabinete de trabajo de los escritores, taller de los dibujantes» — señala Ricardo Baroja- «Desde las dos de la tarde hasta las horas de la madrugada iban de un café a otro. Asomaban de vez en cuando por la redacción de algún periódico para colocar artículos, versos, monos» ${ }^{23}$.

Del café de la Montaña y del de Madrid, sus centros de operaciones más habituales, una facción, encabezada por Benavente, pasó a sentar sus reales en la Cervecería Inglesa, en la esquina de la carrera de San Jerónimo con Echegaray; otra, más revoltosa y bohemia, con Valle y Manuel Sawa como pontífices máximos, pasó a la Horchatería Candela en la calle Alcalá, frente al ministerio de Hacienda. Poco después, hacia 1903, literatos y artistas plásticos encontraron acomodo definitivo en el café musical Nuevo Levante, en la acera izquierda de la calle Arenal, y allí permanecerán hasta su dispersión en los años de la primera guerra europea. El papel de este cenáculo artístico en la innovación creativa española de los primeros años del siglo $\mathrm{XX}$ ha sido justamente ponderada: «El café de Levante — son palabras de ValleInclán - ha ejercido más influencia en la literatura y en el arte contemporáneos que dos o tres universidades y academias». $\mathrm{Y}$ en eciprocidad con esa oposición —añade Ricardo Baroja- «los acadé-

icos, los consagrados, los profesores de los centros de enseñanza oficial arte nos temían como a la peste» ${ }^{24}$.

Fl Ateneo de Madrid es otro de los centros donde la efervescencia actual del cambio de siglo se vive de forma intensa ${ }^{25}$. Por el lado de la agitación política la figura de Joaquín Costa, ateneísta cotidiano, resulta la más representativa del complejo entramado intelectual del final de siglo. Pero en general el Ateneo de esta época es un microcosmos de todo lo que se mueve en esa coyuntura. Nadie lo ha expresado mejor que el, sin duda, más agudo observador de la vida ateneísta, Manuel Azaña: «el impulso dado al Ateneo y el giro que lleva desde hace treinta años -escribe en 1930 - expresan la mudanza sufrida en la conciencia pública. El Ateneo, enteco y casi arruinado, merced a su gravedad en tiempos anteriores, se hizo numeroso, bullicioso y 
libre como nunca. Roto el acatamiento a lo consagrado perdió aquí prestigio cuanto las instituciones de la sociedad española encumbran y avaloran» ${ }^{26}$.

El ambiente ateneísta de estos primeros años del siglo XIX lo recoge Azaña, entre bromas y veras, en un artículo publicado en la revista Gente Vieja, de 20 de marzo de 1903. Bermúdez, hombre joven de ambiciones políticas, se ve en el compromiso de actuar de cicerone de uno de los caciquillos más influyentes del distrito por el que aspira a convertirse en madatario. En esto recalan en el Ateneo.

- «Aquí encontrará usted, amigo don Pablo - decía Bermúdez al entrar en la Docta Casa- además de un excelente café y confortables salones, grata compañía, amena e instructiva conversación, novedad en las ideas, tolerancia para las opiniones ajenas y en los grandes torneos del salón de sesiones, un plantel de maestros de la oratoria, cualidades todas que conquistan para esta sociedad gloriosa el cariño y el entusiasmo de sus miembros» ${ }^{27}$. Una vez dentro, le enseña la biblioteca, «oficina de intoxicación mental y física, donde quien no se aturde con la filosofía se marea con el cok. Todo es uno y lo mismo, que dijo el filósofo»; a continuación el gabinete de lectura, después la Cacharrería, «centro vital del Ateneo, punto de reunión de lo más selecto de esta casa... Ahí el ingenio se desborda, la ciencia despliega su vuelo de águila sin ostentación pedantesca; se miente para pasar el rato, se murmura sin mordacidad, se hace política sin trascendencia, y finalmente se arregla el mundo y se da un orden al universo entre dos sorbos de café y dos chupadas de cigarro, constituyendo uno de los rincones más curiosos y característicos de este Madrid tan digno de ser estudiado». En la Cacharrería, el viejo Echegaray mordiéndose la perilla para sofocar el enojo por alguna impertinencia mal sufrida, por ejemplo, la de aquel joven «de aventajada estatura, melena abundante y cuidadosa, espléndido cuello planchado, escasísima corbata y un manojo de violetas en el ojal». Pasan a continuación por un pasillo «cruzando frente a un grupo de muchachos de extravagante aspecto»:

- «sos que ahí estaban son unos chicos modernistas que juegan a la poesía y a la genialidad... iMás buenos son todos que un pedazo de panj».

Asisten a continuación a la cátedra de un estupendo antropólogo y criminalista (Salillas) y escapan de ella ante la indignación del caciquillo por unas apreciaciones del profesor «poco lisonjeras para los 
habitantes de una provincia castellana, precisamente la del cacique que le escuchaba». Todavía antes de salir del Ateneo tienen ocasión de contemplar a un grupo de sirvientes del Ateneo que rodeaban a un señor, ya viejo, escuchando atentamente la lectura de un periódico y comentándola entre murmullos de aprobación: «tratábase de un discurso pronunciado por un docto catedrático en que se exponían el origen, desenvolvimiento, filiación y porvenir de las ideas socialistas».

«En otro debate característico vinieron a desfogarse los impulsos de rebeldía - recordará también en el discurso de 1930- Formaban piña en el Ateneo algunos sociólogos, de quien no me queda tiempo para escribir los buenos ratos que les debimos. El tema de la discusión sería el socialismo o el anarquismo, no recuerdo bien. Los sociólogos aportaron su dictamen. Junto a ellos concurrían los militantes: Pablo Iglesias, Jaime Vera y otros socialistas, el doctor Madinaveitia, intelectual anarquista; Federico Urales y su mujer, Soledad Gustavo, encargada de leer los discursos del marido; el futuro duque de Maura, tocado de diletantismo socializante; y entre Urales y la Gustavo, un joven entrerubio, rasurado, impávido, que si lo aludía un adversario erguíase en el escaño y, abiertos los brazos, exclamaba: ¡Yo soy un hombre de acción, no de palabraj. El hombre de acción, de pocas palabras, era don José Martínez Ruiz, todavía sin seudónimo» ${ }^{28}$.

Pero fuera de estas implicaciones específicas de tipo intelectual y artístico se puede extraer de las anotaciones de la biografía madrileña del 1900 que estamos glosando una categoría general expresiva de la forma en que se vertebran en España los diferentes espacios de la vida nacional en el gozne entre los dos siglos: es la de una concepción centrípeta de la vida nacional, que gravita sobre Madrid, y otra igualmente centrípeta de la sociabilidad madrileña, especialmente de la artística, que se aglutina en el espacio formado por la Puerta del Sol y sus alrededores. Sería descabellado atribuir a la capital una particular identidad que hiciese de la tertulia un rasgo específico de madrileñismo castizo, de forma que, como recuerda Mariano Tudela, hasta las reuniones provinciales del mismo género no fuesen más que ensayos generales en los que el tertuliano se preparaba «para su salto a Madrid, tal vez a la conquista de la Puerta del Sol» ${ }^{29}$. Sin duda, no es por ahí por donde van los tiros. Pero no cabe duda de que determinadas corrientes profundas de la vida nacional del siglo XIX tienen como efecto secundario un reforzamiento en la capital de estas formas rituales y lúdicas de las relaciones sociales. En concreto, que la vida social se distribuye en torno en líneas de fuerza guiadas por el centro gravitatorio de la Corte y de las nuevas instituciones del gobierno repre- 
sentativo, de forma que durante el siglo XIX buena parte de las antiguas noblezas locales y de las nuevas burguesías económicas y especialmente políticas pasan a residir en Madrid; que, igualmente, la vida académica nacional está trazada desde el vértice de la capital y que en el campo artístico ejerce una poderosa fascinación para la febril inquietud creadora de los jóvenes provincianos. «Es el sueño dorado del poeta de provincias -observa Pérez Escrich-Desde el rincón de su modesto hogar, contempla a través de un prisma fascinador una sociedad y unos hombres que admira sin conocer» ${ }^{30}$. Todavía en esta época - y sobre la llamada generación del 98 se ha puesto de relieve con frecuencia ${ }^{31-}$ Madrid sigue contando de forma decisiva como centro de formación y de consagración artística, a pesar de que en Cataluña el movimiento cultural equivalente, el noucentisme, tenga ya como uno de sus signos distintivos el de mirar hacia otro lado - hacia París especialmentepara no toparse con el rostro provinciano de la capital. No cabe duda en consecuencia que por todo ello las características universales de la relación social se encuentran aquí considerablemente reforzadas. Unamuno, habitante de una típica ciudad media española, como Salamanca, decía temer Madrid por esta especial intensidad de su vida de relación: «es decir, me tengo miedo a mí mismo cuando voy allá. Cuando estoy en la Corte, cada noche me retiro a casa pesaroso de haber ido a la reunión o tertulia a que fui y haciendo propósito de no volver a ella, para reincidir al día siguiente» ${ }^{32}$.

No es ciertamente solo el café, aunque ésta sea la institución más representativa de una forma de sociabilidad universal y democrática: «la única asociación verdaderamente libre, igualitaria y limpia de dogmatismo y oligarquía, la institución más independiente, los modernos senato-consultos, donde se reúnen los españoles en secciones sin presidencia ni objeto», en palabras de Ramón Gomez de la Serna ${ }^{33}$. La tertulia es en general el líquido amniótico de múltiples actividades cotidianas, ordinarias o lúdicas: las tiendas, las fuentes, las salas de armas, las reboticas, las redacciones de los periódicos, las librerías. De estas últimas Espina nos menciona para el final de siglo la de Fernando Fé, en la carrera de San Jerónimo, con Campoamor, Manuel del Palacio, Eugenio Sellés, Núñez de Arce, Castro y Serrano, Tamayo y Baus, Ricardo de la Vega, Peña y Goñi, Navarrete, Joaquín Dicenta, el conde de las Navas y a veces Castelar»; y la de Murillo, en la calle de Alcalá a la que acuden Menéndez Pelayo, Barbieri, Colmeiro, Fernández Duro y, ocasionalmente, Cánovas, hasta su muerte, Silvela, Pidal y al marqués de la Vega de Armijo» ${ }^{34}$. Y por supuesto, la taberna, centro básico de sociabilidad de los ámbitos sociales populares, aunque 


\section{Madrid 1900. Sociabilidad, ocio y relaciones sociales}

también en este final de siglo, según Espina, iniciase su andadura por los terrenos de las musas, a iniciativa de Manuel Paso, Pedro Barrantes, J. Dicenta, los actores Riquelme y Ontiveros y otros, hasta formar escuela entre la más arrastrada bohemia literaria ${ }^{35}$.

Instantáneas. Primera: un grabado coloreado de Casariego (Museo Municipal de Madrid) nos muestra el escenario del café de Levante en 1875. En un imponente escenario de altos espejos murales, arcadas y llamativas luminarias se agita un hormiguero humano sin apenas resquicios: hasta el fondo de la perspectiva, hombres de pie, tocados los más con sombreros de copa, en animada discusión con otros también de pie o sentados en las apiñadas mesas, entre los que se mueve algún agobiado mozo de servicio.

Segunda: una estudiada composición del fotógrafo Christian Fanzen plasma la redacción de la revista Blanco y Negro hacia 1893. En torno a una mesa central cubierta de papeles varios periodistas parecen afanados en sus ocupaciones profesionales. Todo en derredor, de pie en su mayoría, se distribuyen cuidadosamente varias figuras en actitudes diversas. A la izquierda, en distinto plano, dos tríos hacen tertulia. A la derecha otras parecen concentrarse en su trabajo. En primer plano, a la izquierda, una figura sentada fuerza la pose fotográfica. Todo ello dentro de un escenario de maderas nobles y cornucopias, en el que hace de referencia central una enmarcada portada de la revista de grandes dimensiones ${ }^{36}$.

El café de Levante en 1875.

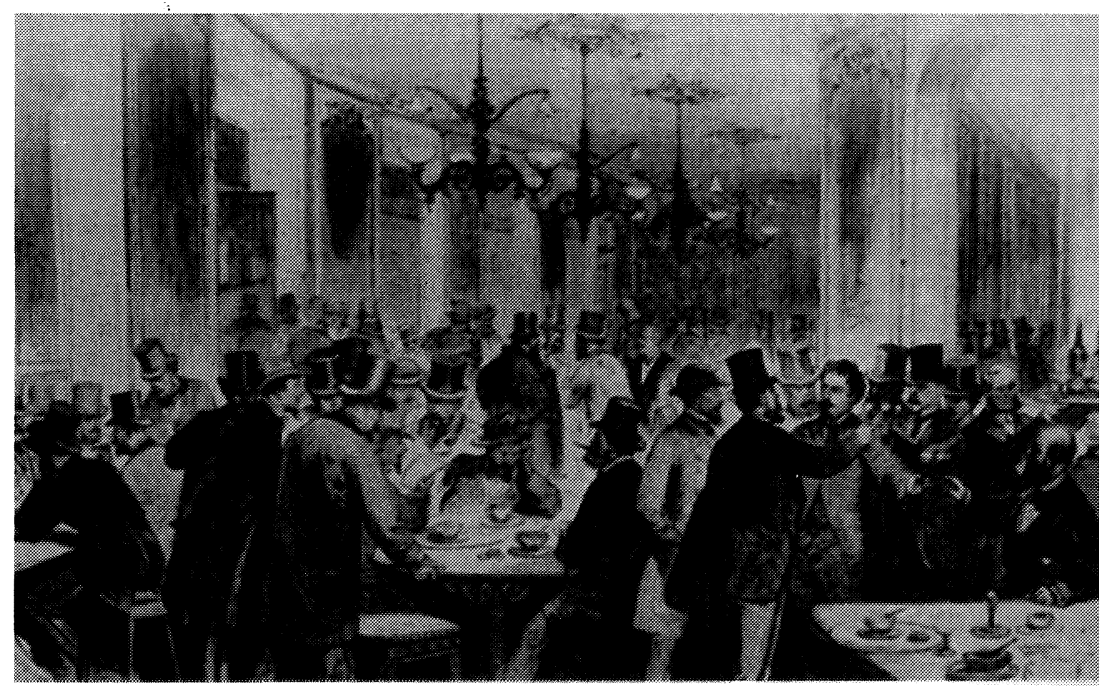




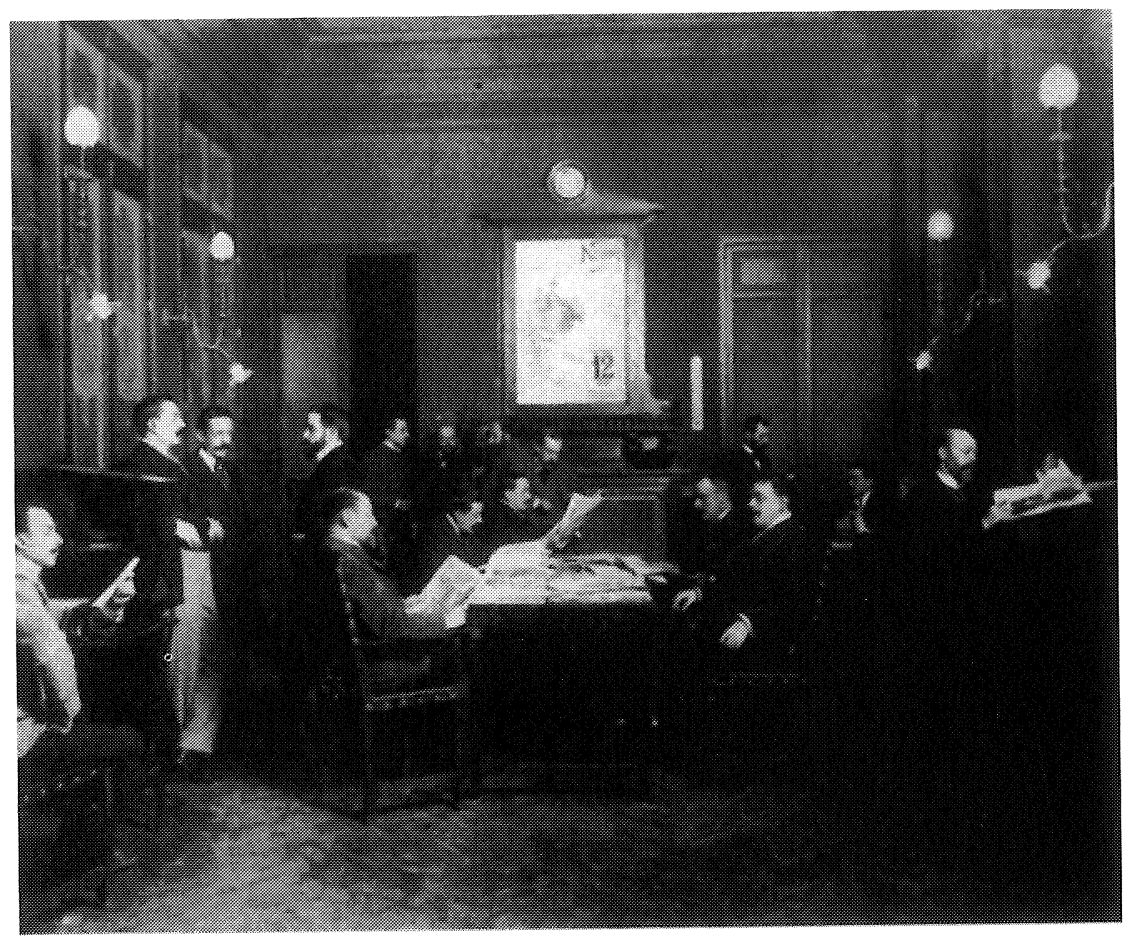

Todos estos espacios se emplazan en un perímetro urbano que tiene como centro físico y simbólico la Puerta del Sol. Pocos cambios hay en esto entre las descripciones que nos dan cuenta de ella en el siglo XIX y las que, por poner un testimonio bien conocido, nos proporciona Cansinos Asséns para las primeras décadas del XX: en todos los casos, una encrucijada, si ya no física desde que la reforma la convirtió en plazuela, de las costumbres, celebraciones, sucesos, acontecimientos políticos, clases sociales, bohemias de todo el país ${ }^{37}$; «una especie de ágora donde pululaban literatos bohemios y filósofos cínicos», lugar de desembocadura donde se forman corrillos perennes, día y noche, mentidero y patio de Monipodio ${ }^{38}$. En cada esquina de su contorno se asienta un café, que pervive o cambia de nombre, pero siempre fiel a su función y a su medio: el Lorenzini-de las Columnas-Puerto Rico-Londres, el Oriental, el Universal, el Levante, el Imperial-de la Montaña, el Correo, el Comercio-Lisboa, el Colonial. En las inmediaciones, en un corto radio, el Pombo, en la calle Carretas, todavía en este final de siglo un sórdido cafetucho sin la historia literaria que le dará Gómez de la Serna; el Madrid en Alcalá/carrera de San Jerónimo, 


\section{Madrid 1900. Sociabilidad, ocio y relaciones sociales}

la Iberia, y la Cervecería Inglesa, en esta misma calle, el Diván-Salón y el Gato Negro, en la calle Príncipe, el Nuevo Levante, en Arenal, el Fornos y el Suizo, fronteros, en el cruce de la calle Alcalá con Peligros y Sevilla respectivamente, repletos ambos de historia tertuliana. El Fornos sería, de todos ellos, el café madrileño por excelencia: escenario general de la vida y de la múltiple condición humana ${ }^{39}$ En el Suizo pervive aún por estos años de final de siglo la peña formada por el periodista Manuel del Palacio antes de la revolución del 68. Su reforma del momento ha sido un reservado selecto, el Suicillo, destinado a «verdaderas señoras y caballeros» escolta, pero no a hombres solos, por lo que todas las noches se forman, a la salida de los teatros, varias tertulias aristocráticas (de señoras, la mayoría con trajes de noche, para tomar un chocolate con ensaimadas) (p. 56). En un radio más amplio, el del Prado, favorito de Ramón y Cajal, y la Luna, en las calles homónimas, este último, centro de operaciones de Eduardo Barriobero, Zamacois y Ernesto Bark y más delante de la arrastrada bohemia bautizada por Carrere como la Cofradía de la Pirueta ${ }^{40}$; el Platerías, en la calle Mayor/Herradores, el Progreso y el musical El Vapor en la plaza del Progreso, el también musical Español, en la calle Carlos III/Vergara, evocado por Arturo Barea en las primeras páginas de su Forja de un rebelde, y, en fin, el de San Millán, junto al mercado de la Cebada, uno de los más periféricos, en la frontera ya de un territorio de tabernas, aprovechando el tirón de los tratantes, comerciantes, almacenistas, transportistas, que llegan por una de las arterias nutricias de Madrid, la calle de Toledo. Solo una selecta relación, no obstante, del casi centenar de cafés de tertulia del Madrid de la época: noventa y dos menciona Espina para 1880; setenta y cinco para 1914, al tiempo que se multiplican los «tupis», pequeños cafés de paso, sin mesas ni divanes, y comienza el imperio de los bares ${ }^{41}$.

Retornemos al libro-lazarillo que nos guía por la biografía social del Madrid de 1900. Es posible discriminar en él un tercer ámbito de sociabilidad que, aun encarnado en fenómenos sociales y en espacios físicos concretos, que señalaremos a continuación, se incardina propiamente en mecanismos identitarios y en formas de diálogo simbólico de reconocimiento-extrañamiento en las relaciones entre distintos grupos sociales. No son pocas las anotaciones al respecto y con ellas es posible construir una estructura arquetípica de esas relaciones y de los canales culturales de comunicación interclasista de la España del momento. Tal arquitectura podría ser acotada desde una vertiente por el concepto de casticismo aristocrático, que tantas veces, al menos desde el siglo XVIII, ha empañado a ciertos observadores, y no sólo 
extranjeros, la percepción exacta de las diferencias sociales en España. Podría abordarse, por otra, desde la percepción de una sociedad regida aún por pautas de comportamiento antiguo en las relaciones entre las clases sociales. La fina observación de A. Espina sobre el intenso sentido convivencial del Madrid del siglo XIX, que favorecía, a pesar de sus enormes diferencias, una fuerte «infiltración» entre las clases sociales, una infiltración regida por un agudo sentido «doméstico», puede servir como marco de referencia de buena parte de las fórmulas de reconocimiento simbólico que nos proponemos esbozar. En el fondo, siguiendo la imagen utilizada por este autor, la circunferencia nacional tenía como centro común de referencia el puchero del cocido. Aunque la calidad de sus ingredientes variase considerablemente, «todo eran garbanzos» ${ }^{42}$. Tal sentido doméstico impregna buena parte de los antecedentes de relación interclasista presentados en el texto y los criterios de percepción social del otro. En este sentido, transciende la frontera de la relación cuasifamiliar específica a que hace referencia para convertirse en una categoría general indicativa del tipo de relaciones predominantes entre la clases sociales de aquel momento.

En términos generales, buena parte de esta sociabilidad interclasista tiene su momento en las celebraciones del Madrid religioso y festivo. Es el momento en que la comunidad eclesial convoca universalmente a los fieles a la comunión espiritual y, ya de paso, a su apéndice pagano, aunque éste termine por contaminar de su sentido lúdico la severidad de la liturgia religiosa. En mayo es el cuadro goyesco de la pradera de San Isidro, vibrante de colores y músicas, en el que se introduce a media tarde, en medio del entusiasmo popular, la Infanta Isabel acompañada de la condesa de Toreno (pp. 202-203). Días más tarde, «medio Madrid popular y parte del aristocrático» se dan cita en Aranjuez para asistir a la fiesta de su patrono San Fernando, (pp. 205-206). El doce de junio es la verbena de San Antonio, junto a la ermita de la Florida, con la presencia de nuevo de la Infanta Isabel, junto a la marquesa de Nájera y Alonso Coello (p. 210).

Otro canal de comunicación se despliega en torno al mundo de las relaciones amorosas. El autor nos narra la bohemia de salón de algunos de sus amigos aristócratas que han alquilado una guardilla, que llaman El Parnaso (p. 99-102), donde imaginan dedicarse al arte. En realidad, a tenor de sus descripciones, resulta un mero pretexto para, fingiéndose Rodolfos, recrear en el dorado ilusionismo de la bohemia literaria un espacio accesible de relaciones amorosas con su Mimí de turno, alternativa a la rigidez de los hábitos sexuales intraclasistas de los grupos dominantes, algo, por otra parte, bien conocido 
Madrid 1900. Sociabilidad, ocio y relaciones sociales

en las descripciones de la literatura burguesa de la época y que ha dado lugar a algunos arquetipos literarios femeninos bien conocidos: la chulapa y modistilla española, la grisette y lorette parisina, la süsse Mädel vienesa.

De hecho, ni siquiera este enmascaramiento literario de los impulsos sexuales juveniles resulta estrictamente necesario. El autor observa en sus anotaciones de enero el escándalo público producido en aquellas fechas por la juerga alcohólica de algunos aristócratas, primero en la calle y después en los burdeles de las calle de la Libertad y San Marcos, sin que la autoridad, dada la alta representación social de los interesados, fuese capaz de calmar los ánimos ni poner remedio. Aunque excepcional por su magnitud - añade nuestro autor- el escándalo no resulta diferente de otros de la misma índole, que suceden en una serie de «tascas», de garitos y casas de mal vivir, donde «al socaire de un andalucismo de pandereta se reunen en bacanal las Venus de cartilla y hospital con los Bacos de morapio, muchas veces de "Carta blanca" y algunas de la "Viuda"» y que continúan su juerga hasta el amanecer, bien en los merenderos de los arrabales, si es verano, bien en los reservados del Fornos o en los sótanos del Casino que llaman «la cueva» (pp. 58-63).

Excurso. Los merenderos son a los arrabales lo que las tabernas al extrarradio urbano y a los barrios populares: centros básicos de sociabilidad de las clases populares (fonda, restaurante, salones de baile, juegos, atracciones, a veces baños), que ocasionalmente sirven de exótico refugio para las aventuras galantes de los señoritos desocupados. Se emplazan por todo el arrabal madrileño, aunque con preferencia en torno a algunas zonas. Una de las de mayor arraigo es la de Ventas y sus calles de descenso hacia el arroyo Abroñigal. Allí se localizan por el final de siglo el Angulo, El Partidor, las Ventas del Espíritu Santo, el Tío Barriga, La Gloriosa, Los Andaluces, Liberto y Conejo, El Toledano. Pero sin duda la zona preferida de los madrileños se localiza en las riberas del Manzanares, en la salida por el camino del Pardo en lo que hoy es el parque de La Bombilla, donde se asientan un buen número de ellos: Los Cipreses, Casa Juan, Los Viveros de la Villa o Casa Lázaro, el Campo de Recreo, La Bombilla, el Cantarranas, El Recreo Madrileño, el Niza, el Santiago Pérez (en el camino de la Fuente de la Teja), el Mariano del Álamo. Hay además otras zonas de menor concentración de establecimientos: la del Puente de Vallecas (El Paraíso, El Manchego, El Numancia, El Pilonero, el Comercio), la de la Fuente del Berro (el Chirumba), la del Sur, entre las actuales calles de Cáceres, Batalla del Salado, Embajadores y Palos de Moguer 
(La Manigua, El Paraíso, La Parra, El Fundidor), la de Cuatro Caminos (Canuto) y otros numerosos dispersos por toda la geografía del arrabal madrileño ${ }^{43}$.

Los toros son otro de los hábitos de sociabilidad tradicional en que se ritualiza la proximidad física y cultural entre las clases. Espectáculo ritual por excelencia, la fiesta pauta rítmicamente el calendario lúdico desde el domingo de Resurrección, que inaugura la temporada, hasta el otoño con la especial electricidad vital que acomete a «ese ser híbrido al que llamamos colectividad» ante la aventura del riesgo y el espectáculo de la muerte. Belleza, colorido, arte, valentía, símbolo, rito antropológico son algunas de las convenciones culturales del género, cuando se desarrolla conforme a ciertos cánones sociales que hipostasian lo real en lo simbólico, no en otro caso, como más adelante veremos. Las caravanas de carruajes por la calle de Alcalá antes y después del festejo son en sí mismas un espectáculo para aquellos que no pueden acceder al núcleo de esa expresión del «alma social». Confundidos los simones del pueblo con los milores y landós de la aristocracia y con las jardineras de los toreros marchan todos "en una especie de apoteosis» a la vez de la comunión colectiva y de la diferenciación social: «carniceras de Lavapiés y las Rondas», "prenderas de la Ribera de Curtidores», "ninfas de picos pardos», trotaconventos y celestinas, floristas y chiquillería al lado de los nombres propios de las beldades oficiales del momento: las marquesas de Alquibla y Portazgo, la condesa de San Luis, la señora de Castellanos, la marquesa de Bolaños, la chica del duque de Almodóvar... (pp. 169-173). Todo ello se repite asiduamente en los meses de bonanza meteorológica. Incluso la amistad antigua, socialmente desigual, del autor con un ahora triunfante espada, Lagartijillo Chico, le permite completar el cuadro desde el propio centro del escenario: la tensa espera antes de la corrida con su cohorte de allegados, incluido un "marqués taurino", la procesión hacia la plaza, el triunfo, la apoteosis callejera, la invitación del marqués en el Casino, las felicitaciones de algunos socios: Mariano Benlliure, Pepito Sabater, Natalio Rivas, el duque de la Roca, Melquiades Álvarez, Gerardo Láncara y Bermúdez de Castro, Perico San Ginés, el pintor López Mezquita; a continuación asistencia a la cuarta de Apolo y el final en la Bombilla, en el merendero Casa Juan, bailando schotis y pasodobles con unas peripatéticas encontradas a la salida del teatro (pp. 177-190).

Rito antropológico, mezcolanza social y un cierto sentido doméstico en las relaciones entre las clases están también en otro interesante apunte de final de año: la asistencia del autor a un baile, de los 
Madrid 1900. Sociabilidad, ocio y relaciones sociales

antiguamente llamados de candil, invitado por El Niño de la Cleta, hijo, ya mozo, de una antigua cocinera de la familia. El baile tiene lugar en la «Rosa Blanca», un local de la calle de Tudescos, semejante a otros muchos del mismo género («La Costanilla», en la Costanilla de San Pedro, el Olimpo y el Lucientes en el barrio de Tabernillas, el del Norte, cerca de Noviciado, el Morrongo, nombres de menciona el autor, p. 290) y todo allí parece ritualizado conforme a esa máscara de casticismo y flamenquería que ha quedado plasmado en las piezas más convencionales de la comedia española y del género zarzuelero: los alias castizos, la habanera y el schotis ceñidos, la sangría de tintorro con melocotón, la retórica teatral del intercambio convivial y una estética de capas, mantones, pañoletas y farolillos venecianos.

Excurso. El baile es uno de los recursos más universales de la sociabilidad desde Palacio a la más humilde verbena. Contamos afortunadamente con el documentado estudio tantas veces citado sobre el qué, el cómo y el dónde bailaban los madrileños a lo largo de los dos siglos precedentes, a partir del cual lo correcto sería preguntarse más bien dónde no lo hacían cuando la causa y el momento resultaban propicios para ello. El repertorio de espacios de esta actividad resulta, en definitiva, el mismo que el de los espacios de la vida social, en general: la corte y los salones privados, los teatros (en el final de siglo, el Alhambra, La Zarzuela, el Apolo, el Madrid-Barbieri), las verbenas y romerías, los merenderos, los jardines de recreo y, por supuesto, los salones y sociedades específicamente dedicados a este arte, numerosos en todo Madrid y en todas épocas.

Sobre el reverso de estas manifestaciones del viejo rancio casticismo nacional puede entreverse también en la biografía madrileña del 900 que comentamos el impacto de las nuevas relaciones sociales, es cierto que no siempre de forma muy explícita, aunque sin duda con un inequívoco sentido de extrañamiento social: lo expresa a su pesar el paradójico "Madrid intransitable y muerto", con que el joven aristócrata protagonista despacha la reseña de la fiesta del trabajo el primero de mayo, después de sugerir la manifestación obrera y las alegres celebraciones de las clases populares en las riberas del Manzanares (p. 192). Pero la percepción de ese mundo es esencialmente el del impacto físico y moral del inframundo de la suciedad y la pobreza: el contrapunto social y urbano de la escenografía brillante de los salones, los paseos, los teatros, el ministerio, la universidad o el similor romántico de la bohemia literaria, que son los que frecuenta; un mundo que adquiere, en virtud de esta operación de acercamiento/extrañamiento una nueva categoría de visibilidad que establece las condiciones de 
percepción de las identidades colectivas y de las relaciones entre los grupos sociales. Dos apuntes son muy significativos al respecto, ya que encadenan toda esa nueva percepción a dos discursos tradicionales extraordinariamente arraigados de la relación desigual y de la singularidad premoderna: el discurso de la caridad y el del exotismo romántico.

En el primer caso se trata del episodio que lleva a nuestro protagonista a compartir unas horas con las clases populares en solidaridad, espectáculo taurino incluido, para con las familias de tres obreros muertos, dos de ellos sacrificados infructuosamente en la tentativa de salvación del tercero. La descripción del escenario - del mísero barrio de Tetuán de las Victorias y sobre todo del propio espectáculo taurinohace visible la realidad primordial oculta tras las convenciones culturales que gobiernan en otros contextos esas representaciones de la «lucha bestial» a muerte entre seres vivos — de hombre a hombre, de hombre a bestia- y el propio destino colectivo que lo ha reproducido en la historia y la cultura de la nación: «que el débil, el pobre, el enfermo, es vencido por el fuerte, el rico, el sano»; que esta «terrible, pero saludable lección se funde... con todo el realismo del arte español, el desencanto amargo del Quijote, el desprecio por el dolor y la muerte de los españoles, la filosofía acre de Quevedo y Gracián, los monstruos velazqueños, las carnes torturadas, la epopeya de América», y en definitiva, con el «problema del destino histórico universal y glorioso de la raza» (pp. 68-69).

En el segundo apunte el protagonista acompaña a Federico de Madrazo y dos amigas francesas de la más rancia aristocracia por los bajos fondos madrileños a la búsqueda de un exotismo apache y romántico entrevisto en la literatura francesa desde Merimée a Louys y Tallon. Lo que entreveía como excitante viaje literario por escenarios misteriosos, hembras fatales, estética decadente, picaresca literaria y amores satánicos se desvela en definitiva como un puro y simple «descenso a los infiernos» de la miseria, la suciedad el hedor y la delincuencia. «Ustedes sólo concebían - les reprocha finalmente el cicerone- el Madrid de la duquesa de Alba, el de la plaza de toros, el del Museo del Prado; pero no esta España de aguafuerte, en cuyo seno acaso se está incubando algo atroz» (pp. 293-297).

Y si tales apuntes tienen sentido más allá de la anécdota concreta que les sustenta es porque este desvelamiento, este derrumbe de las máscaras rituales y literarias resulta, en definitiva, la experiencia primordial de todo el año y así se expresa sintomáticamente en el prólogo y el epílogo de la obra, como si se tratasen de las piezas maestras 
que completan el esqueleto de todo el período histórico que se extiende entre el año descrito, 1900, y el año de descripción, 1945: «Flores, frivolidad al exterior; odio y rencores ocultos al interior. He aquí como se me presenta, visto en perspectiva, el año 1900», el baile de ricos y pobres sobre "un volcán que había de estallar un poco más tarde» (pp. 4-5); «brillo y resplandor por fuera. Al interior, un derrumbe que avanza secreta e inexorablemente» (p. 300), un derrumbe que es básicamente - razón social del pesimismo- el de un mundo que cambia y que arrastra en ese torbellino del cambio a los individuos y a los grupos sociales.

\section{Notas}

1 Puerta del Sol, a principios del siglo XX, de la Fototeca del Patrimonio Histórico. Instituto de Conservación y Restauración de Bienes Culturales. Archivo Moreno. Reproducido en Imágenes del Madrid antiguo. $1^{a}$ parte. Álbum Fotográfico 1857-1939. Madrid, Edic. La Librería, 1996, ilustración 58.. También con una perspectiva más reducida en la portada de MONTOLIÚ, Pedro: Madrid, 1900. Madrid, Silex, 1994. Una muy útil guía de la topografia madrileña del final de siglo XIX es la de Madrid en 1898. Una guía urbana, Dir. V. PINTO CRESPO. Madrid, FUAM-Ediciones La Librería, 1998.

2 Una perspectiva más abierta, que llega a captar lo que creemos un pedazo de toldo del Suizo es la catalogada con el número 1885 de Postales antiguas de Madrid. Recuerdos de un Madrid vivido. Madrid, Edic. La Librería, vol. III, 1994, pp. 390-391.

3 Paseo de Recoletos y Palacio de Linares, h. 1905. Recogido en SÁNCHEZ VIGIL, J. M. Y DURÁN BLÁZQUEZ, M.: Madrid en Blanco y Negro. Madrid, Espasa, 1992, p. 215.

4 Paseo del Prado, 1891, ilustración 65 de Imágenes...

5 Postal catalogada con el $\mathrm{n}^{\circ} 343$ de Postales antiguas...., vol. I, p. 103.

6 Compañy: Paseo de Coches del Retiro, en SÁnchez VigIL, J. M. Y DURÁN BLÁZQUEZ, M.: op. cit., p. 194.

7 Postal 166. Madrid, recogida en MARIBLANCA CANEYRo, R.: Bailar en Madrid 1833-1950. Madrid, 1999, p. 54.

8 Instantánea 42 de Imágenes...., s. p.

9 Postal recogida en MARIBLANCA, obr. cit., p. 57.

10 Flores, A.: "Una madrugada en 1899", Ayer, Hoy, Mañana, t. III, Madrid, ontaner y Simón, edición de 1893, p. 159.

11 El libro a que hacemos referencia es el de Almagro SAN MARTín, Melchor: Biografía del 1900. Madrid, Revista de Occidente, $2^{a}$ edición, 1944, que nos servirá de utilísima guía a lo largo de todo este trabajo. "Así como por el conocimiento de un único hueso puede el naturalista rehacer el esqueleto entero del animal, así, por el estudio de un año, realizado atentamente, podríamos conseguir, quizás, calar en el tono de todo un período histórico", p. 2.

12 SAMUEL, Raphael: "La lectura de los signos", Historia Contemporánea, 7, 1992 , p. 54.

13 Instantánea 1071 de Postales antiguas... vol. I, p. 53.

14 Ilustración 163 de Imágenes del Madrid Antiguo... 
$15 \mathrm{Al}$ respecto, SAlazAR, B. de: La Gran Peña, 1869-1969. Madrid, 1969; MonTERo Alonso, J.: Historia del Casino de Madrid y su época. Madrid, 1971. Sobre el Casino realiza su tesis doctoral actualmente María Zozaya Montes. Algunos datos sobre el Nuevo Club, que espera aún una monografía detallada, en VIllaCORTA BAÑOS, F.: «La vida social y sus espacios", en Los fundamentos de la España liberal (1834-1900). La sociedad, la economía y las formas de vida. Coord. e introd. Por A. FERnÁndez GARCIA, t. XXXIII de la Historia de España Menéndez Pidal. Madrid, Espasa Calpe, 1997, pp. 661-725.

16 Algunos datos de su vida en estos años, PARDo BAZÁn, E.: De siglo a siglo (1896-1901). Madrid, 1902.

17 Recogida en Montoliu, P.: Madrid en 1900..., p. 119.

18 Datos históricos sobre ellos en ARIZA, Carmen: Los Jardines de Madrid en el siglo XIX. Madrid, El Avapiés, 1988, pp. 242-253.

19 Datos al respecto en ARIZA, obr. cit., pp. 228-255 y MARIBLANCA CANEYRO, obr. cit., pp. 41-52, con el plano completo del proyecto de Nuevos Campos Elíseos.

20 Una evocación en BEDMAR, Enrique G.: «El café Imperial», en Madrid por dentro y por fuera. Guía de forasteros incautos. Madrid, 1873. Edición de la Asociación de Libreros de Lance de Madrid, Madrid, 1996, pp. 371-377.

21 Algunos de estos personajes, especialmente Cornuty, Schmitz, Bargiela y otros tienen semblanza particular en el libro de R. BAROJA: Gente de la generación del 98. Ed. de Barcelona, Juventud, 1969.

22 VASILI, P.: La societé de Madrid. Paris, 3ëme ed., 1886, p. 243.

23 BAROJA, R.: Gente..., p. 17.

24 Ibídem, p. 63. Sobre el Nuevo Levante y Valle Inclán CANSINOS ASSÉNS, R.: La novela de un literato (hombres-ideas-efemérides-anécdotas...), vol. I: (1882-1914). Madrid, Alianza, 1996, pp. 140-143.

25 Algunos datos al respecto en Espina, A.: Las tertulias de Madrid. Madrid, Alianza, 1995, pp. 213 ss. Evocaciones de esta etapa ateneísta en GARCÍA MARTI, V.: La vida de un español del siglo XIX al XX. Madrid, Espasa Calpe, 1941, pp. 101-108 y El Ateneo de Madrid (1835-1935). Madrid, Dossat, 1948, pp. 211-229. Asimismo, Villacorta Baños, F.: El Ateneo Científico, Literario y Artístico de Madrid (1885-1912). Madrid, CSIC, 1985.

26 AZAÑA, M.: "Tres generaciones del Ateneo", en $O O$. CC., t. I., México, Oasis, 1966, p. 631.

27 «Tardes madrileñas, II. El Ateneo», en OO. CC., I, p. 48. Artículo completo, pp. $48-52$.

28 AZAÑA, M.: «Tres generaciones...», p. 630.

29 Tudela, M.: Aquellas tertulias de Madrid. Madrid, El Avapiés, 1985, pp. 9-10.

30 PÉReZ EsCRICH, Enrique: "El saloncillo del Teatro del Príncipe», en Madrid por dentro..., p. 23.

31 "Madrid", titulaba el capítulo IV de su libro La Generación del noventa y ocho P. Laf́n Entralgo. Madrid, Espasa Calpe, novena edición, 1979, pp. 70-88.

32 Citado en EsPINA, A.: obr. cit., p. 157.

33 Gómez De la Serna, R.: Pombo, Madrid, edic. de 1986, p. 16.

34 EsPINA, obr. cit., pp. 211-212.

35 Ibídem, p. 213.

36 En SÁNChez Vigil, J. M. y DURÁN BlÁZqUez, M.: obr. cit., p. 33.

37 Una descripción de M. del PALACIO en Madrid por dentro...., pp. 9-13. 


\section{Madrid 1900. Sociabilidad, ocio y relaciones sociales}

38 CANSINOS Asséns, R.: La novela ..., 1, p. 113. Algunas notas sobre ella en Bonet CoRreA, A.: «La Puerta del Sol de Madrid, centro de sociabilidad», en "Plazas» et sociabilité en Europe et Amérique Latine. Paris, Publ. de la Casa de Velazquez, 1982, pp. 69-80.

39 Sobre el Fornos, Velasco ZaZo, A.: El Madrid de Fornos. Retrato de una época. Madrid, 1945. También Espina le dedica una interesante evocación: Las tertulias...., pp. 236-239.

40 ESPINA, Las tertulias..., pp. 239-242.

41 Sobre los cafés, en general, y los madrileños en particular: BONET CORREA, A.: "Los cafés históricos", Discursos leidos en la Real Academia de Bellas Artes de San Fernando. Madrid, 1987; DiAz, L.: Madrid, tabernas, botillerías y cafés, 1476-1991. Madrid, Espasa Calpe, 1992. Numerosos datos también en Velasco ZAZO, A.: Paronama de Madrid. Florilegio de cafés. Madrid, 1943.

42 EspinA, A.: Las tertulias..., pp. 103-104.

$43 \mathrm{Su}$ historia documentada se encuentra en el libro de MARIBLANCA CANEYRo, R.: Bailar..., especialmente, pp. 53-59 y 183-204. 